\title{
"I See God Out the Back of My Farm" Exploring Christianity and Sustainability on New Zealand Farms
}

\author{
By \\ Kelly Koon
}

\begin{abstract}
A thesis
submitted to the Victoria University of Wellington

in fulfillment of the requirements for the degree of

Master of Arts

in Religious Studies
\end{abstract}

Victoria University of Wellington

2020 


\begin{abstract}
This thesis explores the relationship between Christianity and sustainability within the context of rural New Zealand meat and dairy farmers. Looking at the various definitions of sustainability that were given through my fieldwork in the Waikato and Nelson/Golden Bay areas, I describe the contested, ambiguous, and diverse understandings of sustainability that farmers employ. Within this contestation, I explain how Christianity plays a vital role in farming practices and beliefs. Using in-depth case study analysis, I explore the textured and nuanced ways that farmers engage, critique and support sustainability on their farms. Questions of sustainability are explored through farmers' descriptions of their relationships with both their land and surrounding communities.
\end{abstract}


Acknowledgements

I would like to express my thanks to supervisors Dr. Geoff Troughton and Dr. Philip Fountain. Their support, guidance, and wisdom have been one of the greatest gifts, and my thesis would not be what it is without them. Special thanks must also be given to Vida Long, whose constant friendship as we both navigated our MA research was one of the most cherished parts of this often difficult year. Finally, I would like to thank Kristel van Houte and family, David and Kirsty Newton, Richard and Leentje Thorpe, Martin and Lily Emo, Joyce Wylie and family, and Robin Boom and family for hosting me during my fieldwork travels.

The deepest gratitude must be given to the farmers I met with during my research, and I am forever thankful for all the thoughts and opinions that I was able to glean from my fieldwork. I would like to thank each and every one of the farmers that I met with for taking time out of their busy schedule to meet with me. The hospitality shown through meals, cups of tea, tours of the farm, warm beds to spend the night, opportunities to help out with farm chores, and the multitude of interesting conversations did not go unappreciated. Thank you all for welcoming me into your homes and sharing your worldview with me. It has been a wonderful privilege. 


\section{Table of Contents}

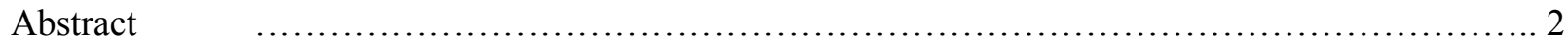

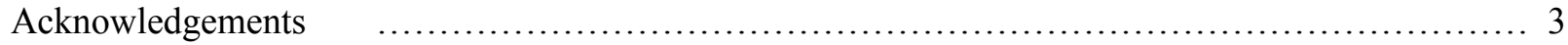

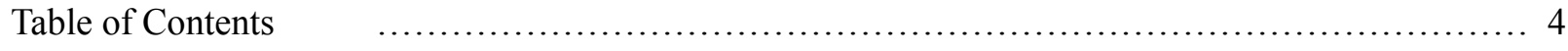

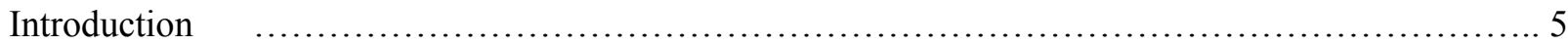

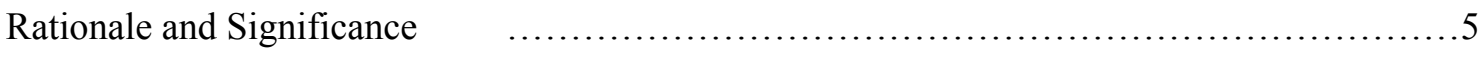

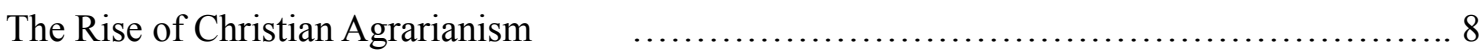

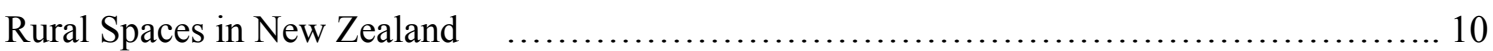

The Problem of Defining Sustainability ................................................. 13

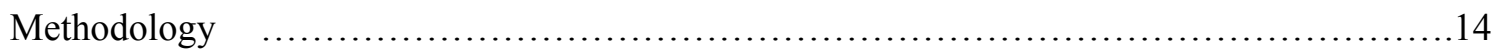

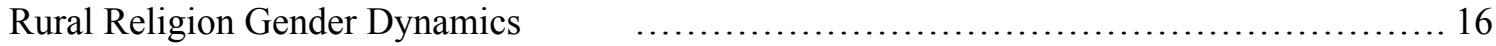

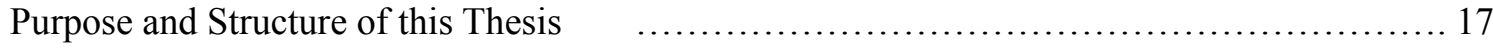

Chapter One - Tensions of Sustainability $\quad$.......................................... 19

Sustainability: "A Difficult Thing to Answer" $\quad$..................................... 19

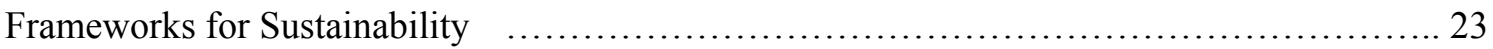

Practical Sustainability and the Husband/Wife Team $\quad$................................ 25

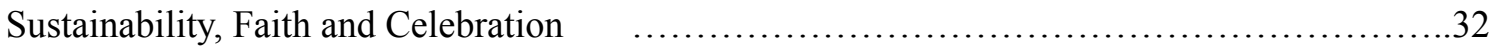

The Problematic Nature of Sustainable Agriculture $\quad$.............................. 38

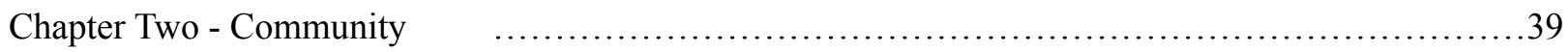

The Necessity of Community in New Zealand to Sustain Farmers $\quad$.................... 40

People are the Reason and Farming is the Means $\quad$..................................42

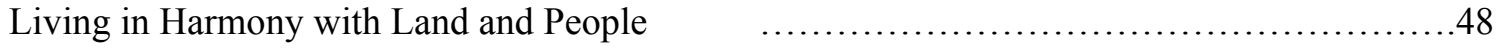

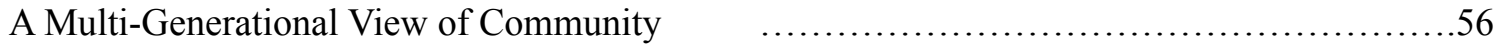

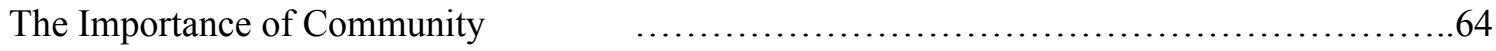

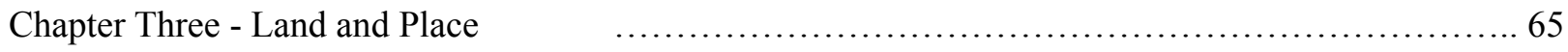

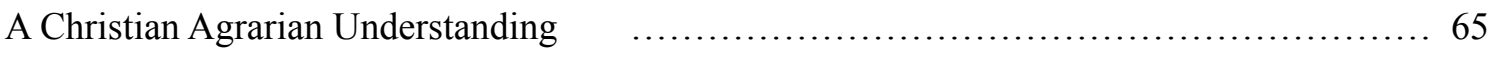

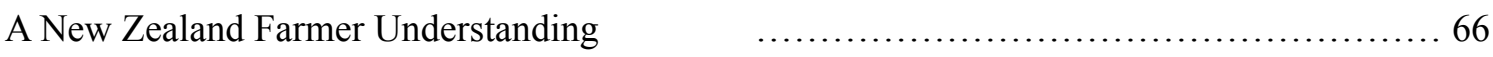

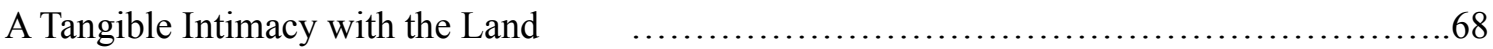

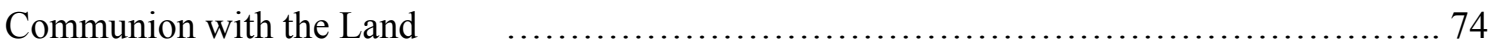

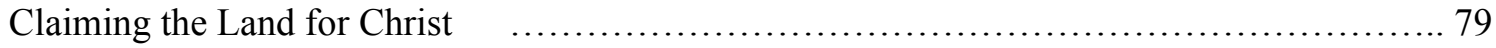

The Various Levels of a Grounded Faith $\quad$..................................... 86

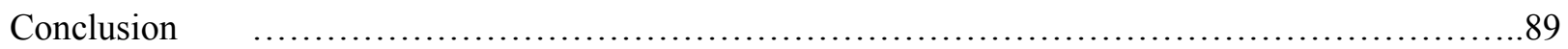

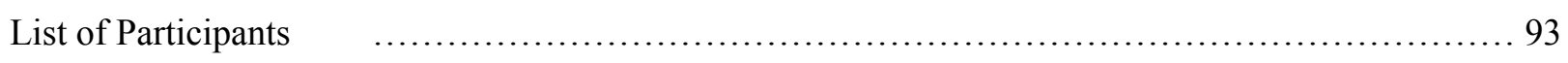

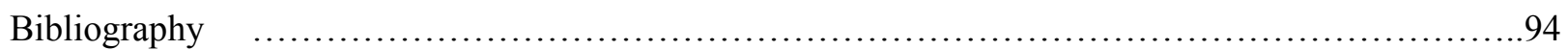




\section{Introduction}

This thesis explores the lives of rural New Zealand farmers and how their Christianity influences and impacts their engagement with the land, animals, and community around them. My research takes into account the environmental and ecological issues that currently surround farming in New Zealand, the Christian engagement with these environmental and ecoagricultural issues, and the lives and Christian beliefs of the New Zealand farming community. I ask questions about how rural farmers view the conversation around sustainability and whether or not their definitions, and the practices that result, have any connection to their personal spirituality. Sustainability is a notion that has increasing relevance to farmers, whether because of their own values or because of its growing prominence within governmental regulation and broader public discourse. However, its meaning is problematic and under continual negotiation, and Christianity is often implicated and evoked in a range of ways within this contestation. For Christian farmers, their faith is imagined as highly relevant to their farming practices, including their treatment of the land and their engagements with their rural communities. However, the ways that it is made relevant differ between farms, and a straight-forward causal argument about faith producing certain environmental outcomes - whether positive or negative - is too simplistic. Farming and faith are brought together in consequential, but not predetermined, ways.

\section{Rationale and Significance}

Globally, there is considerable controversy concerning the state of industrial agriculture and its role in the current ecological, social, and human health crises. ${ }^{1}$ Current problems, as a recent feature in The Guardian notes, include rising air pollution, high greenhouse gas emissions, biodiversity loss, food miles, the use of chemical fertilizers and pesticides, and the use of chemical antibiotics. ${ }^{2}$ These issues, as well as the growing demand for food resulting from an ever-increasing worldwide population, have placed additional stress upon farmers who face

\footnotetext{
1 John Vidal, “A Switch to Ecological Farming Will Benefit Health and Environment - Report," https:// www.theguardian.com/environment/2016/jun/02/a-switch-to-ecological-farming-will-benefit-health-andenvironment-report (accessed 31 March 2019).

2 John Vidal, “A Switch to Ecological Farming,” https://www.theguardian.com/environment/2016/jun/02/ a-switch-to-ecological-farming-will-benefit-health-and-environment-report (accessed 31 March 2019).
} 
financial pressures due to the national and global food system. Many farmers disregard more sustainable agricultural measures for larger industrial practices, which promise consistent and more lucrative results. However, ecological farming techniques are also being employed to prevent further environmental destruction. These techniques include crop rotation, limits on synthetic fertilizers and pesticides, prohibition of GMOs, encouraging diverse ecosystems to create good soil fertility and pest control, raising free-range and better treated animals, and various land specific farming practices. ${ }^{3}$ A dilemma is thus created between balancing environmental sustainability with ensuring a livelihood.

New Zealand has not been immune to the effects of environmental concern and industrialization within the farming communities, especially given that agriculture is one of the country's primary industries. While New Zealand has focused on branding itself as "clean and green," and steps have been taken to decrease food miles and focus on the localization over globalization of goods, the country is far from perfect in regards to sustainable agricultural practices. The restructuring of the country's economy in the 1980s and the opening up of the global market caused within farming communities a dramatic reduction of incomes and land values and an increase in debt, from which many have still not been able to recover. ${ }^{4}$ This focus on increasing the global economic market has caused the farming community to address what it means to be sustainable while also lucrative, and how much they are willing to change their farming techniques in response to these tensions.

As farming has intensified within New Zealand, so have the environmental effects. In 2017, the Public Perceptions of NZ's Environment survey found that 59\% of respondents saw farming as a major cause of environmental damage; $65 \%$ of respondents saw farming runoff as being managed quite poorly. ${ }^{5}$ Fear of water pollution within New Zealand has elevated, with a December 2018 Colmar-Brunton poll finding that $82 \%$ of people were concerned about river

\footnotetext{
${ }^{3}$ Oana, “The Importance of Ecological Farming," https://agronomag.com/importance-ecologicalfarming/ (accessed 14 May 2019).

4 Sarah Johnsen, “Contingency Revealed: New Zealand Farmers' Experiences of Agricultural Restructuring,” Sociologia Ruralis 43, no. 2 (2003), 128-129.

${ }^{5}$ Scoop Politics, “Top Environmental Issues: Water, Agriculture, Climate Change,” http:// www.scoop.co.nz/stories/PO1702/S00203/top-environmental-issues-water-agriculture-climatechange.htm (accessed 25 March 2019).
} 
pollution, higher than the concern around the cost of living and personal health. ${ }^{6}$ The Department of Conservation has explained that any environmental good the recent decrease in sheep and beef farming might have done has been overshadowed by the damage that dairy farming continues to inflict, as much dairy farming is practiced on flat countryside and on irrigated and intensively fertilized pastures that are close to water sources. ${ }^{7}$ The need to produce results that are economically viable and the need to practice sustainable agriculture that pays attention to the environment are therefore opposing forces for New Zealand farmers.

While the relationship between daily farm tasks and the faith of the farmer may not initially be obvious, there is a tie between the two, for the community it brings is vital for the maintained life of the farmer. Christianity has had connections to the farming community of New Zealand, with some farmers finding support through churches and groups such as the Fellowship of Christian Farmers International. Failure, shame, and isolation have become factors for many New Zealand farmers as the viability of agricultural practices and sustainable soil and water are in question, as well as the global concern for food supply and justice. ${ }^{8}$ As Robyn McPhail notes, for many Christian farmers the question becomes "How then do we get sucked into sidelining the Christian way and its wisdom of sustainable sufficiency? What prevents us from holding together the needs of soil, people, and economics?" 9 For some farmers within New Zealand, there is confusion and ambivalence in regards to how to be stewards of the land and animals they work with while continuing to keep up with demands from the economy and environmentalists. Biophysical, economic, and cultural characteristics of an area are all important influences upon how a farm runs and what agricultural processes the farmer will utilize, and this includes the Christian faith of the rural area and the rural farmer. ${ }^{10}$

\footnotetext{
6 RNZ, "Water Pollution Now Public's Top Concern," https:/www.radionz.co.nz/news/national/379343/ water-pollution-now-public-s-top-concern (accessed 26 March 2019).

7 Department of Conservation, Protecting New Zealand's Rivers, PDF File, 11.

${ }^{8}$ Robyn McPhail, "Theological Reflection on Sustainable Farming and Sustainable Rural Communities," Knox Centre for Ministry and Leadership (2008), 9.

9 McPhail, "Theological Reflection," 6.

${ }^{10}$ Sarah Johnsen, “Contingency Revealed: New Zealand Farmers' Experiences of Agricultural Restructuring," Sociologia Ruralis 43, no. 2 (2003), 146.
} 
There has been some engagement, as noted above, between Christianity and the farming community in New Zealand. However, there is still much to learn regarding how, if at all, faith interacts with rural farmers' sustainable agricultural practices, as well as what it means to practice "sustainable agriculture," given that the term itself is highly contestable, for "different people identify the objects of sustainability differently."11 Within New Zealand there are multiple interpretations of what it means to be sustainable, especially when comparing environmental activists calling for reform to farmers working on the land. Is the fair, sustainable treatment of the land and the animals that individuals work with a purely economic maneuver, or does it have a moral component? By focusing on New Zealand farmers and their definitions of sustainability, along with focusing on their Christian faith, this thesis examines the intersections and relationships between these elements.

\section{The Rise of Christian Agrarianism}

The conversation around faith and sustainable agriculture has taken particular shape elsewhere, for example North America, where industrial-scale agriculture predominates. These developments have motivated the creation of literature from a range of scholars, many being Christian, who desire a movement back to agrarian ideals. This study is in part inspired by the rapid growth of the movement in the context of the United States, as my personal interest in the topic arose from reading Christian Agrarian writers while working as a whole animal craft butcher in North Carolina. In addressing the ongoing crisis between ecological concerns, the growing agricultural demand, and the livelihood of the rural farmer, prominent writers on the topic, including Wendell Berry, John Ikerd, Ellen F. Davis, Kyle T. Kramer, Norman Wirzba, and Joel Salatin, have been vocal in their advocacy for an agricultural practice that cares for the land and the animals that are a part of the system. They call the modern world to be mindful of the relationship between agricultural practices and chemical, biological, economic, cultural, philosophical, and religious knowledge. The focus of the writers, theologians, and farmers who are part of this movement is on an intense and intimate knowledge of place, seeing faith in relation to locality as key to better treatment of the earth.

\footnotetext{
${ }^{11}$ Michael Redclift, "Sustainable Development," in The Companion to Development Studies, ed. Vandana
} Desai and Robert B Potter (London: Arnold Publishers, 2002), 276. 
When using the term "agrarian," I will be following the definition that Norman Wirzba gives: "Agrarian writers argue that the way we think about reality - the meaning of God, community, and earth - is dependent upon where we are. More specifically, it is dependent upon the perception and the sympathies that develop as the result of our making a home within a particular place." 12 Knowing one's place is, therefore, of the upmost importance to the discussion around sustainable agriculture and spirituality. It is through knowing and loving a place that care of creation, both local and universal, can be cultivated. For Ellen F. Davis, "Agriculture involves questions of value and therefore of moral choice, whether or not we care to admit it."13 By bringing biblical resources into the conversation concerning important and increasingly more urgent ecological issues, a relationship between the community and the land can be understood as a vital part of agricultural practices. As Wendell Berry writes, "We must change our lives, so that it will be possible to live by the contrary assumption that what is good for the world will be good for us. And that requires that we make the effort to know the world and to learn what is good for it."14

For Christian Agrarians, sustainability tends to be framed through a holistic definition that includes the social, economic, spiritual, and environmental. John Ikerd defines sustainable agriculture as being "about meeting the needs of the present without compromising the future, which requires harmony and balance among the ecological, economic, and social dimensions of agriculture. But sustainable agriculture also is about the pursuit of a desirable quality of life materially, socially, and spiritually - rather than the pursuit of narrow individual self-interests." 15 A holistic understanding is necessary for the sustainable lifestyle of both farm and farmer. ${ }^{16}$ Ikerd notes that, "Some see sustainability as only an environmental issue. They are wrong. It is an environmental issue, but it also is much more."17 What Ikerd means is that there is a spiritual

\footnotetext{
12 Norman Wirzba, “Agrarian Ecotheology,” Theology 116, no. 1 (2013).

13 Ellen F. Davis, Scripture, Culture, and Agriculture (New York: Cambridge University Press, 2009), 22.

14 Wendell Berry, The Art of the Commonplace (Berkeley, CA: Counterpoint, 2002), 20.

15 John E. Ikerd, Crisis \& Opportunity (University of Nebraska Press, 2008), vii.

16 Ikerd, Crisis \& Opportunity, 12, 71-72.

${ }^{17}$ Ikerd, Crisis and Opportunity, 77.
} 
dimension to sustainable agriculture, and he says, "To farm and live sustainably is to farm and live spiritually. Sustainability is not a religion, but it is undeniably spiritual. To farm and live sustainably, we must be willing to reclaim the sacred in food and farming."18 The study and practice of sustainability is not purely scientific, for agriculture cannot omit social and spiritual values. ${ }^{19}$

Christian Agrarianism calls for the intimate collaboration of faith and farming, understanding the sacredness of the world and the requirement of correct treatment and care. The people involved in the movement are conscious of the way in which biblical principles inform their sustainable agricultural practices, articulating this consciousness in their writings. This growing body of literature shows that there are people who see a close connection between religion and agricultural sustainability, and that this movement is growing in popularity within certain contexts. However, while these writers seem to support the claim that sustainability and Christianity influence one another, there are a number of separations between Christian Agrarians and the farmers I interviewed: academic/scholarly/theological versus everyday, America versus New Zealand, normative versus descriptive, and published books and articles versus interviews. These issues created some of the core questions that I tested in my fieldwork. Within my thesis, I propose that the sentiments of Christian Agrarians are also evident among meat and dairy farmers living and working in New Zealand. However, there is a distinct different amidst conceptions of the way the world "should be" regarding a relationship between Christianity and sustainability, and the way it actually is. One function of my thesis is to bring greater understanding to this difference.

\section{Rural Spaces in New Zealand}

Compared to literature about faith and farming in the States, which continues to expand, the literature around rural religion in New Zealand is sparse. This is surprising, given that New Zealand's primary industry is farming and the majority of farmers who are religious identify as Christian. One significant voice is that of Presbyterian minister and farmer Robyn McPhail.

\footnotetext{
18 John E. Ikerd, Crisis \& Opportunity (University of Nebraska Press, 2008), 91.

${ }^{19}$ Ikerd, Crisis \& Opportunity, $\mathrm{x}$.
} 
Originally from Southland, she shifted to the far north of the North Island. Her writings on rural ministry encompass both spaces of Christian theology and rural ideology. In the compilation Land and Place: Spiritualities from Aotearoa New Zealand, McPhail describes that "her heart is in the land and in the gospel, with energies directed primarily to the well-being of local communities, to people working together and developing sustainable partnerships with one another and with the land and sea we rely on even if we don't realize it." 20 McPhail's insights into the rural space directly related and helped to make better sense of my fieldwork experience.

Being Pākehā, her view of the environment was similar to many of the farmers that I met, whose connection to the land was embedded in historical processes of colonization. The way in which McPhail speaks about rural relationships towards the environment is insightful, and she combines Christianity and sustainability for the rural New Zealand context. She notes that "To be rural [is] to know your neighbours and know that you need them and they need you. Discussing the weather [is] never simply small talk: it [is] essential to picking up others' needs and concerns. Sustainability is profoundly Christian and inherently biblical."21

While McPhail has been brought up in a rural farming environment, her scholarship is focused on biblical theology and Christianity, due to her ministerial profession and her academic background that includes a $\mathrm{PhD}$ in Philosophy. She speaks about how there is much tension with what it means to be sustainable while keeping one's farm a viable business:

'It's hard to be green when you're in the red.' This succinct statement expresses perfectly the confusion and the ambivalence of living with integrity on the land. People of faith those who are part of our churches now but also many others who, as experience has shown me, are looking for ways to live and work with the land that is spiritually grounded - are trying to read the unreadable and make choices that are life-giving, in economic terms, and in terms of the viability of the local community and the health of the land. This statement is a plea for understanding that sustainability is a whole of life matter for rural people. They are not saying, do not expect us to be green because it is impossible, but rather help us by recognizing that the issues we face are so entangled that only an integrated approach can make gains. Economic survival, ethics, the common

\footnotetext{
20 Robyn McPhail, "Rural Spirituality" in Land and Place: Spiritualities from Aotearoa New Zealand, ed. Helen Bergin and Susan Smith (Auckland, NZ: Accent Publications, 2004), 116.

${ }^{21}$ Robyn McPhail, "Theological Reflection on Sustainable Farming and Sustainable Rural Communities," Knox Centre for Ministry and Leadership (2008), 4.
} 
good, political negotiation, technical nous and ecological mutuality are all essential for sustaining the place in which we receive and give life. ${ }^{22}$

However, McPhail's understanding is a somewhat idealized, theological frame, rather than an analysis focused on Christians as they are. This is a question of normative versus descriptive approaches. It is also a question of whether the combination of Christianity and sustainability is intentional or whether it is subconscious and potentially accidental in nature.

The role of rural New Zealand churches and communities was something I constantly thought about as I became familiar with the areas I was researching. Conversations regarding lay-led churches, traveling ministers, disagreements and splits between local church communities, the creation of small "Christian cults," and the inability to go to church based upon location and farming responsibility made me increasingly intrigued with what went on in the rural church community. I found that, as McPhail had identified, a key part of sustainable agriculture is the rural community that it takes place within. For the farmer, it is not merely the land and the animals they daily work with. It is also the community that they are a part of, and for a Christian farmer this often includes their church community. If sustainability encompasses economics, environment, social, and spiritual, all of these aspects must be taken into consideration.

I realized through my research that what I was trying to understand was much more tangled than I had at first imagined. This was especially true give the multi-denominational character of rural Christianity in New Zealand. The farmers I met were Christian Zionists, Open Brethren, Church of Christ, Presbyterian, Anglican, Baptist, Methodist, Assembly of God, Catholic, and non-denominational. Some farmers were very progressive in their theology, while others were starkly conservative. Their Christian practices and beliefs generated definitions of both faith and sustainability that cohered and clashed between the farmers I interviewed.

\footnotetext{
${ }^{22}$ Robyn McPhail, "Theological Reflection on Sustainable Farming and Sustainable Rural Communities," Knox Centre for Ministry and Leadership (2008), 13-14.
} 


\section{The Problem of Defining Sustainability}

When I began my research, I imagined that my fieldwork would involve talking with farmers primarily about sustainable practices related to the environment. However, I found that farmers talked about more aspects than I anticipated, invoking the same term - "sustainability" in a variety of ways to connote quite different meanings. I came to characterize these distinct approaches and meanings in the following ways:

1. Sustainability as a response to God's gifts: The farm is seen as a miraculous gift given directly to the farmer from God. Therefore, part of the farmer's job is to be a steward and custodian to the land, animals, and community that surround them.

2. Sustainability as a focus on family: The farm is a means by which social aspects of life might be facilitated. Sustaining the farm means sustaining the people in and around the farm, especially with regards to children who might take over future farming operations.

3. Sustainability as regulatory regime: Sustainable agricultural practices are rules and regulations pushed upon the farmer by the government that often hinder the productivity of the business.

4. Sustainability as animal welfare: To employ sustainable agricultural practices means to treat animals with respect and care.

5. Sustainability as economic viability: Sustainability should be conscious of the financial aspects of the farm. Certain decisions must be made in order to continue a successful business.

6. Sustainability as lifestyle continuity: Sustainability means that not only will the farm continue to work well, but the practices employed will not run down the farmers and their families. Choices made on the farm keep in mind the physical and mental health of the farmer.

7. Sustainability as ecological flourishing: Sustainability means focusing on the environment, taking into account the ecological impact of farming practices.

Based upon the multiple frameworks with which farmers approached and understood the definition of sustainability, I found that there were different emphases for different farmers, as well as a sliding usage of this term. I will use these definitions throughout my thesis, expanding 
upon what the farmers I met with meant when they both consciously and unconsciously expressed their definitions.

\section{Methodology}

The primary focus of my research involved interviewing individuals who identified as Christian and who were currently involved in the professional farming community within New Zealand.23 I conducted semi-structured interviews with these individuals. My initial goal was to interview ten to fifteen people, though in the end I interviewed twenty-five couples, many more people expressing openness to talk with me than was possible. I went into my research hoping to travel to multiple regions of both the North and South Island in order to gain a broader national sample of the faith and farming practices of New Zealand meat and dairy farmers. However, I also wanted to keep my approach open-ended, leaving room for whatever information, connections, and opportunities arose through interviews.

The decision to focus primarily on the Waikato and Nelson/Golden Bay areas of New Zealand was originally unintentional. Rather, conducting fieldwork in these specific places resulted from my usage of the "snowball method" of gathering interviewees. Given that my entire thesis relies upon the thoughts expressed through interviews, the role of the people who introduced me to my farming contacts was vital. As a subset to the snowball method of finding interview participants, a few key gatekeepers not only gave me people to talk to, they also vouched for my trustworthiness as an outsider and stranger. These people included supervisors, mentors, pastors, friends, and organizations such as A Rocha Aotearoa. The significance of the two areas I focus on is based upon the willingness of my initial interviewees to put me in touch with their friends and family members. Originally conducting a week of fieldwork in the Waikato followed by a week spent in Nelson/Golden Bay, I was given so many contacts that I decided to return for another week in each place to meet with more people. While I do not claim that the farmers or communities are representative of New Zealand as a whole, my sample does enable rich insight into certain networks of relationships. This thesis is an empirical study that is

\footnotetext{
${ }^{23}$ Based upon ethical decisions, the names of farmers mentioned within my thesis have been changed.
} Their location and the details of the interview, however, remain the true to life. 
descriptive and qualitative in nature, a decision based upon my desire to research the personal relationship between the Christian farmer and their farm. My research is therefore representative solely of the people I interviewed. It must be mentioned that none of my interviewees identified as Māori. This was not purposeful, as I was open to meeting with anyone as long as they fit my small criteria. Instead, I believe this was a result of the gatekeepers I connected with, for the Christian communities they were a part of seemed to be largely Pākehā. Therefore, it is important to keep in mind that the results and conclusions of my research are solely regarding rural Pākehā farmers that are Christian.

The interviewees were selected on the basis that they (a) identified as Christian, (b) worked on family farms, (c) relied on said farms for their livelihood, and (d) were meat or dairy farmers. The individuals who worked on these farms did not need to be of any political leaning or particular Christian denomination, and the farms they worked on did not need to publicly claim any sort of eco-sustainability or official organic certification. However, I sought farms that operated as "professional" family-owned farms, meaning that the couples I spoke with were more closely connected to their spaces and had agency over the decisions made. Given that I left the identifying factor of Christianity up to the people I interviewed, the denominations of the famers I met with varied. This created a diverse understanding not only of sustainability but Christianity as a religion and spiritual belief system.

The format of my interviews was semi-formal, usually taking place at the dining room table. After consent was given through a signed form, I recorded the interview as well as taking notes. ${ }^{24}$ Most of my conversations lasted for around one to two hours, with the exception of one interview which lasted ten minutes. I designed my interviews and analysis around four main

\footnotetext{
${ }^{24}$ My ethics approach consisted of a signed consent form. The interviewee understood that (1) they were able to withdraw from this study at any point before 31 December 2019, and any information that I provided would be returned to them or destroyed; (2) the identifiable information they provided would be destroyed on 4 March 2025; (3) any information they provided would be kept confidential to my supervisors and I; (4) the findings would be used in my Master's thesis, as well as having the option of being presented at conferences and future publications; (5) my notes and recordings would be kept confidential to my supervisors and I; (6) their real name would only be used in a list of interviewees located at the end of the thesis and utmost care would be taken with sharing their information or opinions; (7) they consented to information or opinions which they gave being attributed to them in any reports on my research; and (8) they had the option to receive a copy of the final report emailed to them.
} 
questions that were the basis for all my fieldwork, although I left space for people to diverge from the interview structure as much as they desired. My four questions were:

1. How long have you been on your farm and what type of farming do you do?

2. What is your Christian background?

3. How do you engage with issues of sustainability?

4. How does your Christian faith engage with sustainability?

I later transcribed the interview recordings myself. At the end of the interview, I asked for a tour of the farm, which sometimes meant assisting with chores as we drove around, and sometimes simply meant being shown the farm boundaries from the house. These tours were generally also accompanied by further conversation, providing rich insight into farmers' contexts and lives. In addition to the actual fieldwork, I read widely about farming in relation to Christian Agrarianism, as well as an overview of New Zealand farming: it's history, the current ecoagricultural issues and discussions, the sustainable techniques and practices being used, the lives of farmers, and the Christian culture of these rural farming areas.

While I conducted twenty-five interviews, I have not included all of them within my thesis. This was a purposeful choice, for the structure of my research focuses on interpreting the specifics of farmers and their thoughts on Christianity and sustainability through case study analysis, rather than a synthesis of the data as a whole. The case studies I include in my thesis capture key tensions and perspectives that are central in expanding my argument. Finally, the purpose of this thesis is to shed light on the rural Christian farming community in New Zealand, and I believe this can best be created through long case study analysis. The interviews I conducted with farmers across the Waikato and Nelson/Golden Bay regions felt like the unfolding of a rarely told story, and therefore I would like my writing style to mimic this narrative approach.

\section{Rural Religion Gender Dynamics}

Unexpected but delightful, the majority of my interviews were held with both husband and wife present, all of my farmers being heterosexual couples. The only time the wife was not present was when they were out with the kids or working another job. The exception was Betty, 
who was the only married woman I talked to by herself, since her husband declined to be interviewed. ${ }^{25}$ This was enlightening for a few reasons. It showed the teamwork that appeared to be integral to farming lifestyles and necessary for sustenance of a farming profession, both parties bringing different skillsets and priorities. In a profession that consumes the majority of one's life, the capacity for husband and wife to work together is central both practically and for mental health. Husband and wife work dynamics also provided me with a more complex picture of how sustainability is employed on the farm. In most interviews I conducted, the husband seemed to be the leader of the farming operation, speaking about the financial aspects, while the wife was often the environmentally conscious one, bringing the topic back to sustainable agriculture practices. This is discussed in Chapter One, where I give greater explanation to the husband and wife's joint role in understanding what sustainability means.

The wife also played a part in keeping the husband on topic, making sure he said the "correct thing" and ensuring I was not going to misrepresent the family. With the tension currently surrounding the farming community in light of environmental issues, it made sense to me that the families would want to be extra careful of an outsider coming in to conduct an interview regarding farming practices. In this way the wife's role seemed to be both the maker of tea and hospitality, as well as the mediator and moderator. There were clear gender roles exhibited through the interviews I conducted, the husband and wife keeping to their sociallyconstructed responsibilities. However, in this dynamic there was also a strong value placed on including both voices and opinions. Therefore, while differentiated gender roles were acted out, there was considerable interaction between these roles. Given these gender dynamics, part of the woman's role in the conversation was also to provide a safety buffer between me as a woman and the husband as a man.

\section{Purpose and Structure of Thesis}

In Chapter One, “Tensions of Sustainability," I begin by briefly detailing my participants' definitions of sustainability, showcasing the problem of trying to find one singular definition. I then delve into two of the interviews I conducted, explaining what a combination of sustainable

\footnotetext{
${ }^{25}$ More about Betty and Nick’s relationship in Chapter Three.
} 
agricultural practices and Christianity might look like. Before conversation can be had regarding how Christianity influences the farmer's sustainable agricultural practices, there must be proper discussion around the multifaceted concept of sustainability. Through these interviews, I introduce the tensions that come with defining sustainability, and how these tensions are dealt with. Sustainable agriculture must be given a framework, especially when interwoven with one's Christian faith.

In Chapter Two, "Community," I discuss the importance of the people in rural spaces and how this became, unintentionally, a vital part of the conversations I had around sustainability. I refer to Robyn McPhail as a basis for understanding the way in which community aids in the sustaining of farmers and their profession in rural New Zealand. I then look more closely at four of my interviews, focusing on the ways in which local, national, and international community considerations can often be a larger driving factor for farming than anything else. I offer up an understanding of community as being the support system for practicing sustainable agriculture.

In Chapter Three, "Land and Place," I address the specific dimensions of the relationship between farmers and the land. I begin by exploring the Christian Agrarian understanding of land and place and what these writers believe the relationship between Christianity and the land should be. I then focus on three interviews, showcasing three different understandings of what the land means and how it interacts and relates to views on both farming and faith. I conclude that meat and dairy farmers in New Zealand adhere to a "lived theology" that is deeply grounded in place, farmers structuring their lives in a layering of Christian responsibility and farming responsibly. The practical reality of isolation, even when farmers are engaged with their surrounding community, means that the land plays a vital role in visions of sustainability.

The purpose of my thesis is to gain a deeper understanding of how rural Christianity and the environmental conversation around farming intersect. The thesis that follows is organized into three chapters that address central themes emerging from my field research. These chapters showcase the wide range of concerns and interests that are a part of the farming profession, as well as examining a language of sustainability that is slippery in nature. Faith and farming practices are deeply connected and consequential, but the ways in which they are cannot be predetermined. 


\section{Chapter One - Tensions of Sustainability}

In this chapter, I explore what the definition of sustainability means to the farmers I met with. I begin by examining the different aspects of sustainability that I encountered in my interviews. I then focus on the interviews of two couples who give greater depth and insight into the problematic aspects of sustainability, looking at their definitions of sustainability, their relationship to Christianity, and the way in which they view the tensions of their farming profession. I argue that agricultural sustainability is a multi-faceted concept, and that it is caught within ongoing tensions between what sustainability "should be" and what it actually is. A view of life steeped in a strong adherence to pragmatism and the "triple bottom line," a term referred to by many farmers which references a business approach seeking financial, social, and environmental goals, has created a definition of sustainability that moves far past good treatment of the land, animals, and community that farmers in New Zealand live and work with. This model when combined with a spiritual basis for decision making gives added depth to an already contested profession.

\section{Sustainability: "A Difficult Thing to Answer"}

While a few of the farmers I met with said that sustainability was "quite simple," the majority understood that defining such a terms was problematic. Before delving into my case studies, the difficulty of defining sustainability must be recognized, as farming practices and beliefs varied between the farmers I interviewed. Some had large hill country farms while others had small flatland dairy farms. Some were the owners of farms that had been in their family for generations, while others were new to farming on their land. Some were elderly retired farmers while others were young and full of new ideas for agriculture. Some desired to stay close to immediate family and friends, while others desired to branch out and get involved in the wider New Zealand farming community. I interviewed only one certified organic couple, although some of the farmers had previously been organically certified before deciding it was not what they wanted. These differences in farming lifestyle and practice meant that there were a multitude of definitions given when I asked farmers what their understanding of sustainability was. This diversity expresses the tensions inherent in farming, a space where care for the 
environment is both necessary for and in tension with other aspects of maintaining the viability of the farm. Christianity is implicated within this problematic definition in a number of ways, as will be evident within this thesis.

I encountered two dominate framings for sustainability, the first being the idea of leaving the land better than it had been, which I will call "the betterment discourse." This discourse was mentioned in the majority of interviews I conducted, with one Golden Bay dairy farmer even acknowledging that sustainability is, "probably what you have heard before - try and leave the land better than what it was when you took it over." The belief in betterment through farming creates many ambiguities, as well as the question of what the term "better" even means, and answers to this were diverse. To some, "better" meant planting the land back with native bush, ridding it of any agricultural footprint, keeping waterways clean, and giving specific areas of the land rest. To others, "better" meant cutting back on stock numbers and creating a less intensive farming system, farming with either organic or biological principles in mind. Some farmers understood "better" to mean taking a deep look into soil biology and working towards increasing soil fertility, while others believed "better" meant making the land more productive so that their business could be profitable. Thus, a tension is created through the nature of a business that requires cooperation between the land, animals, and people, as well as the balancing act between working the land with ecological care and economic profit. ${ }^{26}$

Each of these possibilities of "betterment" were offered during my interviews with farmers. Similar to the definition of sustainability, the concept of betterment is complicated and contested. It becomes a matter of the farmer practicing the type of betterment they deem legitimate while understanding that this might not match the expectations of others. Farmers did not articulate a clear systematic theology of sustainability. Rather, it was ambiguous, hesitant, and messy in its definition. It is my belief that this messy definition is partly a result of the tension they feel between being defensive about their practices, while at the same time feeling a significant burden to further improve practices.

\footnotetext{
${ }^{26}$ Hannah Bartlett, "Renewing the Lungs of the Land," Flint \& Steel 3 (2016).
} 
The second dominate frame for sustainability was the focus on pragmatism, furthered by an adherence to the "triple bottom line" business model. Made popular in New Zealand by Dick Hubbard, founder of Hubbard Foods Ltd., this concept requires businesses to measure success not just according to financial logic, but also according to social and environmental logic. Hubbard's business model for sustainable development, hard work, and fairness has influenced many in New Zealand, including the sheep, beef, and dairy farmers I met with. ${ }^{27}$ The triple bottom line has been an integral part of New Zealand business ethics in recent years, with the Ministry for the Environment publishing an official guide in 2003 explaining how businesses can use it. Through this model, businesses are encouraged to account for their impacts on the environment, other people, and economic systems..$^{28}$ According to the Ministry for the Environment, "Businesses traditionally judge their own performance against one bottom line the financial one. Increasingly, however, they are being asked to consider how they affect the environment and their communities. The triple bottom line is a method that allows companies to assess their performance against three bottom lines: environmental, social and economic." 29 At its most basic, the triple bottom line is practical sustainability as acted out in a business model. Businesses that use this model have mentioned that it reduces operating costs, improves identification and management of risk, creates value through enhanced reputation and positive customer response, increases ability to attract and retain employees, increases learning and innovation, and provides structure and measurement for current social and environmental initiatives. ${ }^{30}$

One of the main focuses of the triple bottom line is the financial aspect, for it is through sustainable treatment of the environment that finances will benefit: "Reducing, reusing and recycling waste, conserving energy and water can all result in cost savings as well as

\footnotetext{
27 Sam Young, "Dick Hubbard," http://www.samyoung.co.nz/2011/03/dick-hubbard-authentic-leader.html (accessed 4 November 2019).

${ }^{28}$ Ministry for the Environment, Enterprise: Your Business and the Triple Bottom Line, PDF File, 6.

${ }^{29}$ Ministry for the Environment, Enterprise, 2.

${ }^{30}$ Ministry for the Environment, Enterprise, 2-3.
} 
environmental benefits." 31 This is the same with social sustainability, as the Ministry for the Environment says, "Demonstrating your commitment to social responsibility will help improve profitability." 32 Therefore, sustainability becomes not just an environmental focus, but also something that can increase your overall business gains. For farmers who have control over their family farm businesses, the triple bottom line model has clear appeal through the promise of a non-agonistic relationship between financial and environmental imperatives. This bottom line has also been given to farmers as a good model of sustainability through Fonterra, as seen in their 2019 Sustainability Report which calls for the triple bottom line goal of "Healthy People, Healthy Environment, and Healthy Business." 33 Likewise, the business plan given by Beef \& Lamb NZ encourages a triple-bottom line approach to results and outcomes on the farm. ${ }^{34}$ While the traditional understanding of this bottom line includes only three elements, religious belief can often add a fourth. Detailed in Chapter Three, couple Ash and Caroline thoughtfully articulated that a "spiritual bottom line" was important to their decisions on the farm, a thought similarly supported by other farmers I had met with. Ash explained that both him and Jan found this model lacking a vital fourth component: spirituality. This bottom line has influenced all they have done, further solidifying their holistic understanding of sustainability:

Sustainability covers the environmental, [the] financial, and, reality is, the social. And there is an element of the spiritual. In this country, in this valley, we have people here that come for healing, rest, and respite. We have a camping ground on the place that we allow people to come and camp freely [upon] when they can't otherwise afford it. It is all part and parcel to the social and spiritual responsibility. We have had people propose, give their hearts to the Lord, we have had baptisms, ... How do you look at sustainability? Well to me it is a combination of all those four things. You can't put it in a box, even though it quite often is just [seen as an] environmental issue. But we see it much wider and larger than that. And every farm is different. Every farmer is different. Every farm has a preference for how it should be farmed.

\footnotetext{
${ }^{31}$ Ministry for the Environment, Enterprise: Your Business and the Triple Bottom Line, PDF File, 9.

32 Ministry for the Environment, Enterprise, 16.

33 Fonterra, "Sustainability Report 2019," https://www.fonterra.com/nz/en/what-we-stand-for/ sustainability/Sustainability-report-2019.html (accessed 20 January 2020).

${ }^{34}$ Beef + Lamb, "Business Plan," https://beeflambnz.com/knowledge-hub/PDF/business-plan-template (accessed 20 January 2020).
} 
Nevertheless, the spiritual is still not the dominate frame in discussion of the triple, or quadruple, bottom line.

\section{Frameworks for Sustainability}

The betterment discourse and the triple bottom line framework are lynchpins for understanding the various definitions of sustainability that I mention in the Introduction. While sustainability is, as one Nelson sheep farmer explained, "a difficult thing to answer," attention must be given to the diversity of such a word. While I attempt to divide this word up into an artificial framework to help with understanding my research, I want to make note that, in reality, it is a bit more messy. In my interviews, frameworks for sustainability were mixed together in overlapping ways that created this problematic understanding filled with ambiguity, contestation, and diversity. As the youngest of my participants, a Raglan dairy farmer in her twenties, told me, "You do what you can and as much as you can, and then obviously you have to put it all in perspective."

One of the major themes often brought up was sustainability as a response to God's gifts of the farm. For example, one sheep and beef farmer in the North King Country expressed that, "God has given us this land to use and to care for." This belief was reiterated by one of their neighbors, who also happened to be the only organic farmer I interviewed: "We pray about everything, and we know that the Lord answers our prayers and guides us. In finding the farm and [in] how we farm. We see things as stewards rather than owners." This farmer, in his explanation of sustainability as stewardship, expressed to me that his decision to be certified organic was less about ecological sustainability and more about a response to the gifts given to him and his family by God.

Another theme of sustainability continually mentioned was lifestyle continuity, which often was combined with the theme of sustainability as a focus on family. Continuity of both the farm and the family were expressed by one Golden Bay sheep and beef farmer: "Sustainability is leaving things for the next generation ..., whether it is our kids or somebody else's kids, in a good place so that they don't have to redevelop or salvage it." With these themes also came sustainability as regulatory regime and economic viability, for to continue one's lifestyle and 
familial wellbeing, the farm had to be a functioning business. This idea often clashed with other aspects of sustainability, and as one particular dairy farmer from South Waikato bluntly explained, "I would like to say that Christianity informs [sustainability], but it might have something to do with shear rat cunning and business continuity over the next thirty years, given the regulations I am facing. So you might do it for both reasons, but if I do a serious self-analysis it is probably more the latter over the former, and this may be wrong." For better or for worse, the farmers I spoke with mentioned the honest reality of what having a farming business meant.

Finally, sustainability as animal welfare and ecological flourishing were two themes that were often less dominate but still discussed within my interviews. On the topic of animal welfare, a dairy farmer I met with outside of Raglan mentioned that, "We have an obligation to be kind, to treat our animals well, and to give them as good a life as we can." In terms of ecological flourishing, one sheep farmer outside of Nelson explained that, "Sustainability is something that can be carried on without having detrimental effects on your land or environment." Even though environmental sustainability, including animal and ecological welfare, was in the conversations I had, few focused on it as the major theme. Many of the farmers I interviewed held tense and ambiguous definitions as a result, practicality being interwoven between all their thoughts on sustainability.

Due to the multi-faceted concept of sustainability, a tension is created between what sustainability on the New Zealand farm "should be" and how it is practiced. A view of life steeped in a strong adherence to the triple-bottom line has created a definition that moves far past good treatment of the land and animals that one lives and works with. As became apparent in my interviews, farmers in New Zealand are constantly having to live out this tension with sustainability. For the purpose of this chapter, I will focus on two farming couples: Carl and McKenzie, dairy farmers in the Waikato, and Jake and Irene, dairy farmers in Golden Bay. While all of the people I interviewed spoke in some capacity about the problem of defining sustainability, these two couples were adamant about actively dealing with these problems, especially with solving various environmental issues. Both couples working as dairy farmers for Fonterra, their differing locations of the Waikato and Golden Bay meant a contrast in how they 
approached practices on the farm. ${ }^{35}$ Both couples also relied on their partnership as a couple to holistically understand sustainability.

In the following interviews, I will explain how these couples not only think about sustainability, but also act it out in their agricultural practices. I begin with Carl and McKenzie, examining the necessary practicality of sustainable agriculture and the various perspectives needed from both husband and wife to accomplish these practices on the farm. I then introduce Jake and Irene, explaining how the concept of rest and celebration are vital for practices of sustainability on and off the farm. I have chosen to examine these two couples in my conversation around sustainability because they gave me the most comprehensive and thoughtful view of how a combination of Christianity and sustainability influenced and impacted their farming. Through these interviews, I unpack what sustainable agriculture means to the farmer, their family, their farm, and their faith.

\section{Practical Sustainability and the Husband/Wife Team}

Part of employing sustainability on one's farm is being practical, recognizing the various pieces at play in the functioning of the farm. Utilizing sustainable agricultural practices also means that teamwork must be present within the decision making process. These combined themes are important for the function of both the family lifestyle and business, as well as the overall relationship with the land, animals, and community around them. I begin with these two baseline themes to express the importance of laying a solid groundwork for understanding sustainability on farms. One such couple that showcased a firm structure for their farming and faith practices were dairy farmers Carl and McKenzie. Bright and early on a Monday morning, I flew into the Hamilton airport and made my way to a dairy farm on a long stretch of road right outside the town of Otorohanga. Down a short gravel driveway with pastures on either side and a large river nearby, I was greeted by Carl. We shook hands as I introduced myself, and he explained to me that his wife McKenzie was on her way back from dropping the kids off at

\footnotetext{
${ }^{35}$ Fonterra is the largest dairy exporter in the world, with products in over 140 countries. See https:// www.fonterra.com/nz/en/about.html.
} 
school. We went ahead and sat down at the kitchen table, Carl pushing aside bills and farm paperwork as we began the interview.

Both raised in Christian families, McKenzie as a Catholic and Carl as a Baptist, the two met through a Christian fellowship group at Massey University. Carl told me how the couple came to be on the farm, having lived overseas for some years before moving back to New Zealand to contract milk for his parents. They then moved onto their current farm in 2005, buying their own small herd and 50/50 share milking. ${ }^{36}$ In 2008, they began 50/50 share milking on a second family farm down the road, running about 600 cows total between the two farms.

When our conversation turned to sustainability, I asked Carl how he would define the term. He gave me his base-line definition, saying,

Sustainability, for me, is to be able to continue to do things year on year for a hundred plus years. So just looking after the soil, animals, people and making sure that whatever you are producing is not mining the system. It is about keeping the soil fertility balanced and healthy. It is about having pastures that are sustainable and that have longevity, having a livestock system that is balanced and supports itself, and having work conditions that people enjoy and continue to support [them]. If it is not ... if people are being turned over constantly, then that is not sustainable in practice. And then [there is] looking after and caring for the land, ensuring that you are not getting lots of soil erosion, that you are not smashing the system and damaging soils, and that you are dealing with nutrients and water properly.

Carl's definition of sustainability highlights looking after one's animals, land, and community together. Longevity and support - of soil fertility, livestock systems, and work conditions - are vital if continuity is the desired outcome. This understanding of sustainability influenced Carl's view of the negative feedback dairy farmers in New Zealand have been receiving. While frustrated by public perception, he did agree there are poor farm practices that need to change. Carl stays off social media and does not get involved in arguments, as he does not think it is effective, nor does he have the time or skill set for online debates. Carl commented on this by saying "I would rather let my actions speak louder, so let's make sure that we are doing effluent

\footnotetext{
${ }^{36}$ Sharemilking is when "two parties come together to run a dairy operation: the person who owns the land and the sharemilker, the person who runs the farm and milks the cows." See Dairy Barn Systems, "Sharemilking and Dairy Farming," https://www.dairybarnsystems.co.nz/knowledge-centre/sharemilkingand-dairy-farming/ (accessed 2 February 2020).
} 
properly, let's make sure we are using sustainable agricultural practices, that we are not abusing the environment, and then making sure that the business is profitable ... It is best to just get on with it really, and accept that there will always be some people who fundamentally disagree with our livelihood." Practical in his approach to criticism, Carl saw the focus of his farming profession as employing proper practices, giving people no reason to express negative comments about his farm.

McKenzie came in the door from dropping off the kids at school and Carl visibly relaxed once his wife arrived. This was the first hint at the team mentality of the couple, as it was clear Carl felt uncomfortable as the sole representative for the family's farm and faith. McKenzie's immediate engagement in the interview questions, asking her husband what he had said and what he had missed out on, further portrayed this dynamic. She promptly began to speak about how sustainability is wider than just environmental: "I think that there are some unique issues to New Zealand in terms of cultural stuff. If the farm is going to be sustainable it has to work with the local indigenous people." Cultural identity, environmental treatment, the importance of the local place you reside - these, according to McKenzie, are all intimately linked together. McKenzie explained that she had gotten to know her neighbors, both Māori and Pākehā, and made it a priority to work together with everyone when approaching environmental issues. She expressed an understanding that "some people seem to be quite compartmentalized - this is our environmental thing, this is our faith, this is our farming, this is our staff." However, for McKenzie, seeking a holistic view of the world is where true sustainability can be found.

Interviewing the couple together provided insights into different definitions of sustainability. Carl equated sustainability with being profitable and focusing on people, while McKenzie brought an environmental and cultural focus. Every decision on the farm required communication between Carl and McKenzie as husband and wife, this being a practical decision that aided in the health and functioning of both the farm and their marriage. McKenzie's current focus was geared towards community projects such as riparian planting along the river bank, as 
well as replanting a one hectare block of original kahikatea. ${ }^{37}$ She was honest with me that this was an action based upon both environmental sustainability and wanting to be respectful of Māori culture. She described her actions as being based on "a big muddle of thoughts" that combined faith, sustainability, and the environment. Carl and McKenzie were distinctive in that they were the only couple to directly mention how their treatment of the environment around them related to local Māori communities. Public perception and cultural perception were both important pieces of the sustainability conversation for the couple. This seemed to me to be another practical decision, as negative perception from either community would mean greater difficulty with sustaining their farm.

I asked the couple if they had any specific examples of sustainable agricultural practices that they utilized on their farm. They described the dilemma of their underpass, which can often become a high risk area for effluent running into public waterways as cows pass under the road from one paddock to another. McKenzie described this as being a real mixture of issues: she did not want effluent getting into the creek as the river was tapu to Māori and she often had "tree huggers" coming onto the farm to help her plant native trees and she felt embarrassed every time they walked past the underpass. While both Carl and McKenzie assured me that the problem had never been a major one, and they already had a system where they could wash the underpass into the effluent system when it was dirty, there was always the potential that effluent would run into the stream when the cows walked through. The couple tried a dewatering system for a year before deciding it was not worth it, feeling frustrated with the difficulty of solving such an issue.

They then decided to build an internal bridge through the underpass so that the groundwater would be kept completely separate from where the cows walked. This system has worked well thus far. Showcasing the way the couple worked together, Carl said, "It got to the point where we were like no, actually we aren't really happy with this, so we need to actually look into it. It has taken a good couple of years to try and figure it all out," and McKenzie added to this saying, "[The underpass] was quite important [to me]. I think it was important to [Carl],

\footnotetext{
${ }^{37}$ Riparian planting is the practice of riparian vegetation, "plants that are adapted to grow in the moist conditions found along the banks of streams, lakes, and other waterbodies," being planted along rivers and streams on and around the farm in order to keep the waterways clean. See Oxford Dictionary of Environment and Conservation, 3rd ed., s.v. "Riparian Vegetation."
} 
but it was quite a difficult issue that we didn't have an easy answer to, so there was quite a bit of perseverance involved and thought to work it out." In relaying their process for arriving at a solution, it became clear to me that the couple worked together to combine Carl's financial shrewdness and McKenzie's environmental priorities to come to a mutual decision. The extensive conversation and deliberation that surrounded the effluent system and all Carl and McKenzie had done to try and mitigate issues suggested how much this desire for sustainable agriculture practices had been on their minds, influencing their farm and marriage relationship. Sustainability, as defined in the telling of this story, was trial and error, patience, persistence, money, time, and thought. After the interview had ended, McKenzie took me to see the underpass. She explained to me how their new system worked, expressing pride and care towards what they had created. Sustainability means being patient, and it frustrated the couple that this patience was insufficiently recognized in public discussions around farming.

In McKenzie's opinion, sustainable farming, especially relating to their underpass dilemma, connected to faith through the combined efforts of their "God-given talent" and the teamwork of the couple. This understanding of how faith interacted with their agricultural practices further showcased the baseline practicality of the couple. Employing sustainability on the farm was a job best done together, and the use of talents given them from God was the best way to combine faith and farming. This teamwork was not without frustrations, as McKenzie expressed to me: "I was quite unhappy about it, but [Carl] didn't know what to do, so I felt like my voice was being ignored." The couple directly connected the issues they encounter with environmental sustainability to their marriage relationship. Sustainability, therefore, becomes a quest for understanding and finding equal ground in decision making. According to McKenzie, "I felt as Christians [that] I didn't want to be hacking off our neighbors or treating things that they see as sacred as just stomping all over it and technically ruining it ... 99\% of the time [we had] clean water, but there was always the potential it wouldn't be ... We said that it needed to change, but no one could give us an answer as to how to solve it." Treating the environment in a sustainable way, according to Carl and McKenzie, was more difficult than it might first seem, for money, understanding, and skillset are all necessary tools that can be hard to come by. McKenzie's primary focus was the cultural and environmental aspects of things, meaning that 
she continued to speak towards all that has and still needs to be done on their farm. Carl, always the pragmatist and business-minded one, kept on interjecting to try and make sure I realized they were not doing anything wrong. He explained that they simply wanted to do things better.

McKenzie brought the conversation back to Christianity by describing how faith provides a sense of rest, just as being sustainable provides rest through the knowledge that agricultural practices are not hurting the environment and the people. By having a holistic understanding of sustainability that works alongside their Christianity, the couple were able to see a complete view of their farm. McKenzie explained this with the example of animal farming, saying, "Yeah, I just find it hard to separate [sustainability] out as any one thing ... We are not just looking at the treatment of animals from a Christian perspective. We also need to farm them and meet regulations and look after the farm land." It was within this view of care for the farm that I understood McKenzie as acknowledging how the Christian faith cannot be the only perspective utilized on the farm. Rules and regulations all played a factor in proper treatment of the land, animals, and people that were a part of the farm. Being a Christian does mean treating animals with respect, but given that their livelihood depends upon animals, they still need to farm them. Through her description, it seemed that this is when Christianity and farming intersect, where ethics and business come together to create a farming morality stepped in practical sustainability.

Having a more holistic perspective on things can aid in the sustainability of both the farm and the farmer. Having a Christian faith also helps with perspective, knowing that the farm is not the only focus. McKenzie showcased this by saying:

This is not our business, this is God's business, and just to support other people through it, this gives us perspective that if this all goes to ruin ... well, actually it isn't reflecting on us. God's actually got some say in it all. And I think that this actually [removes your] business success being linked to your identity. I think there is a lot of depression amongst farmers because [the farm] is too closely linked to who they are as a person. It is pretty all consuming, and people in farming have fairly poor boundaries around their personal time. They can be working seven days a week for three to four months during calving season, which is not sustainable from a personal well-being point of view.

Carl and McKenzie explained that due to poor boundaries, children often have no desire to continue the family business, a sentiment shared by many of the couples I interviewed. If part of 
the definition of sustainability is to help the land continue for future generations, this directly relates to the stress caused by children not wanting to follow in the farming footsteps of their parents. Farming needs to be manageable for the long term if it is to be sustainable, but what does this mean when the younger generation no longer wants to farm? This was a cause of great stress and anxiety for many of the couples I interviewed. Carl and McKenzie mentioned how many young kids are simply dragged along as their parents work long hours on the farm. The children do not want to be farmers because their parents did not take time off to be with the family, and this is something that the couple has been conscious of. One of their philosophies has always been to give their staff time off and to give themselves time off as well. While Carl mentioned that this has cost them quite a bit of money over the years, it has also helped financially because they come back to work on the farm refreshed and ready to make better decisions. It has also helped them enjoy farming more. They have three full-time staff, as well as contract workers running the farm on a daily basis so that Carl can work as a farm consultant during the week. This is due to the fact that their kids are teenagers and Carl and McKenzie want to spend more time with them. Sustainability, therefore, includes being mindful of the entire family, realizing that children are an important part of the farm.

Another thing that is important to the couple is to be supportive of international development. They have been long-term supporters of the Christian NGO "Tearfund" and have also been involved with a dairy project in Sri Lanka. ${ }^{38}$ This overseas mindset was a topic that I came across in many of my interviews. According to McKenzie, the definition of sustainability included a world-wide perspective, giving them "a lot of belief that what we are doing is good." This baseline belief in the goodness of Carl and McKenzie's dairy farming is something that is aided by a global perspective. To the couple, holistic sustainability on the farm included low environmental impact, creating nutritional supplies for the public, and trusting that their work, both for the farm and for God, was inherently good. The usage of this word was intriguing, as it

\footnotetext{
38 Tearfund NZ is a Christian missions organization created in 1975 from Tearfund UK. They work with local community organizations, partnering with them to help end poverty and live out "God's kingdom values of love, hope and transformation." For more information, visit https://www.tearfund.org.nz/AboutUs.aspx.
} 
created a morality towards their actions. It gave their profession and all of their actions positive weight under the often negative portrayal of dairy farming in the Waikato region. Through this case study, it can be seen that a combination of practicality and teamwork dynamics between husband and wife can help in both the sustainability of the family's farming practices and Christian beliefs. These two dynamics provide a basis for greater relationship between farmer and farm, creating more specific celebration of the farm as a space relating to faith.

\section{Sustainability, Faith and Celebration}

With Carl and McKenzie, the baseline understanding of holistic sustainability combined a practical understanding of the word with a team-oriented relationship between husband and wife. These themes were integral in the sustainable functioning of the couple, both in their agricultural practices and their faith practices. At the end of their interview, they began to speak about the "goodness" of the farm, an aspect that helped to remind them of the notion that not everything

can be controlled by them as farmers. Sometimes, sustainability means to let go of control and let God take over. This belief in the inherent goodness of a well-functioning farm was where faith and farming began to interact with one another. The belief in the moral goodness of the farm was a thought similarly shared by Jake and Irene, whose interview expands upon Carl and McKenzie's concluding thoughts. Immediately upon driving into their Rockville dairy farm, I was struck with how beautiful it was. Farming has been a lifelong profession, the couple working as dairy farmers for the past forty years. They have been on their property as owner-operators for twenty years, milking 170 cows. The farm is relatively small and intensive, with fifty-eight hectares and no staff, save the occasional relief labor for milking or family holidays. It is also a self-contained farm, with all the young stock calves raised on the property.

Jake told me he became a Christian when he was seventeen after growing up in a nonChristian family. The couple met at a Christian university organization, the two got married, graduated, and spent a year doing youth work for a Baptist Church. They then came back to Nelson, where Jake worked on a farm while Irene worked as a consultant for the Ministry of Agriculture and Fisheries. During this time they also continued a very active church involvement through music ministry and leadership. 
Moving onto a farm in Golden Bay, the couple became members of a small rural lay-led church. For the past twenty-five years, Jake has held leadership roles in both the music ministry and the eldership. He mentioned that there has been a lot of change in the church since they joined, as the large homeschool families have left and many artists have moved into the area. A lot of the children have also left, causing the church to become a primarily middle-aged congregation. Due to this, as well as the congregation becoming concerned that they were less relevant in their communities, there has been a refocusing, with the church deciding to reengage through "Community Sundays" occurring every other week.

The conversation then turned to that of sustainability. When I asked Jake what his definition was, he mentioned that it was environmental, meaning "my children or the people that take on this land after me will continue to operate it in a way that isn't running down the system." This baseline definition was one that many of the farmers I spoke with had. However, what was surprising was Jake's conscious mention of people other than his children who could take over the farm, for it expressed an understanding that his children were most likely not going to continue the family business. While many of the farmers I interviewed had family reasons for keeping the farm sustainable for generations to come, this was not the case for Jake and Irene. They did not know who was going to live on their land after them, but this did not hinder their care.

Intertwined with environmental sustainability was economic sustainability ("There has got to be an economic underpinning, otherwise there isn't the ability to address some of the more challenging [sustainability] concerns.") and personal/lifestyle sustainability ("It may actually be environmentally sustainable and it may be economically sustainable, but it may actually not be doable long term for the people involved."). I asked him how these ideas played out on his own farm, Jake responding:

With regard to the people and personal factors, we had a large family and so when they were young and we had lots of energy that was great. It was good, we homeschooled the children ... As the children grew up and moved on and our debt levels were less... we [were] not as financially motivated to survive, then we started to get a little bit tired of the long hours because we had no staff. Typically in the summer people would come and visit this beautiful area with the beaches. They would come and stay with us and they would 
go off to the beaches and we would go off and work on the farm ... We got a consultant in and said "...It is not sustainable for us personally to continue doing this, we are getting older and losing motivation and all that sort of stuff."

Jake and Irene began to change the way that they farmed due to their desire to have a life outside of the farm. They had a small cow shed which meant that it took longer to milk a lot of cows, so they ended up reducing their herd size and converting to once a day milking after Christmas. 39 Reducing the herd size meant that milking periods were shorter, while milking once a day meant that in the summertime there was more free time during the day, helping with the sustainability of their lifestyle. These changes enabled them to look at the next phase of their lives: selling the farm and moving to a retirement area. Jake and Irene wanted to enjoy what they were doing on the farm. Their choices were based upon a practical understanding of their current life stage, as well as a desire to not become burnt out and end up only seeing the negatives of the farm. Now that they have children and grandchildren, their priorities have changed. A change in life requires them to have a light grasp on the farm, and they are actively looking to sell in the next couple of years. Jake said, "I see that as a part of sustainability, because otherwise you will become grumpy old resentful farmers that are victim to our farm." Having a light grasp on the farm does not mean treating it badly, but it does mean taking things less seriously. Sustainability means letting go of the farm when you know you need to, always being able to celebrate the lifestyle through periodic resting.

Jake went on to talk about environmental sustainability, seeing the attention around intensive farming as good. While not all of the negative critiques have been valid, there are areas that have been over-intensified, and these practices should be reconsidered. To Jake, farming was not an assumed right, and proper thought must be placed upon environmental impact:

In general before someone develops a farm, they should consider the environmental effects of running a farm of that type on their property. And yet, [for] the last 20 years we have seen farms develop in some parts of New Zealand that don't have a high summer rainfall ... so they have assumed that they have been able to develop the farm and

\footnotetext{
39 Once-a-day milking post-Christmas is a strategy often used during dry summers, this method reducing the stress on both cows and staff members. See DairyNZ, "Once A Day Milking," https://

www.dairynz.co.nz/milking/once-a-day-milking/ (accessed 2 July 2019).
} 
therefore they will be able to get water there, no matter what their environmental footprint will be.

Some of the ways in which the couple has been working to mitigate their environmental footprint include the planting up of waterways. This has been a primary focus for Irene, who has put in about 3,800 plants in the past two and a half years. An ongoing project, the couple has developed their own nursery, growing all the plants on their land and transplanting them during April-June. There is no profit in the planting. Irene told me that they simply do it because of the environmental benefit of keeping the waterways clean of effluent through riparian planting. Planting along waterways, according to Irene, was also a good idea because it made the farm look beautiful:

I think for me there is this overarching sense of wanting to leave the land at least as good as it was if not better, which is what motivates me to do the tree planting and keep going week after week. It isn't the profit-making. It is just wanting to leave the land well, and just being delighted with the gift that it has been to us, and living out of this delight really. And not wanting to pillage the land ... your farm hasn't been raped. We haven't done any damage while trying to look after all aspects of the land and the animals and the plants.

Sustainability, for Irene, was not supposed to be financially motivated, but rather motivated out of a desire for personal and environmental wellness. This understanding was different to Carl and McKenzie, who appeared more conscious of the financial pressures placed upon sustainable agriculture decisions. While practicality appeared to be a major influence for them, Irene saw celebration and delight as larger driving factors. The metaphorical use of "rape" was a consistent theme both in Irene's thoughts and those of many other farmers I met with. For Jake and Irene, not "raping" the farm meant looking after every living aspect of it without doing damage. A farmer can care for and delight in his farm without hurting it. Similar sentiments were expressed by Carl and McKenzie through violent words such as "hacking" and "smashing," and other farmers also used these metaphors in discussion of environmental treatment. I give detailed discussion into this word choice in Chapter Three's case study on Ash and Caroline.

In terms of Christianity affecting their farming, Jake explained that "As Christians, dealing honestly with people is a high priority, [as is] being ethical in the way that we conduct 
our business. Paying bills on time, just basic things like being honest and truthful, trying to be good neighbors, ... trying to strengthen up the community fabric a bit, because that social side of things is so important when you have mental health and everything else." Faith is a practical necessity, bringing people together and helping to encourage the local farming community. Due to this, the couple has often had small meetings at their house with other families, coming together to talk about their faith as well as other pressing issues. Part of sustainability is community, a characteristic that I discuss in Chapter Two.

Similar to Carl and McKenzie, one aspect of farming and Christianity that the couple spoke about was their treatment of animals. To Jake and Irene, it is important to treat their animals with dignity:

As Christians we have that sense to look out for what we have been given, a mandate to steward creation and also that presence of the Holy Spirit which gives you that sense of "Is what I am doing really in line with what I profess as a Christian?" ... For me to raise a cow - to raise it, to butcher it - all on the farm, is great. We do send cows away to the [meat]works, but I have no problem with killing a cow that has been raised well, that has grown up in a nice environment, and has had a good life. I see that as a part of the natural order of things. And that is the other side of environmentalism. As a Christian I don't see that these animals are like people on four legs. I don't anthropomorphize them. I respect them as part of creation and I steward them as part of that, but I don't give then human rights.

This view of animals is especially relevant when it comes to bobby calves, described by Jake and Irene as one of the least palatable parts of their job. ${ }^{40}$ Trying for a while to raise all of the calves, they were losing a large amount of money. The couple now keeps whatever calves they can, but have to let the rest go. However, this does not mean that the lives of the bobby calves are unimportant. Irene told me about a truck driver who was handling the calves roughly. Upon seeing this, she told told him, "While you are on this farm, you will treat these animals with dignity." Even though Irene expressed frustration towards people anthropomorphizing animals, her respect and care towards them was evident through her desire to treat them humanely. Irene proudly shared that many visitors have said they liked coming to the couple's farm, as the

\footnotetext{
${ }^{40} \mathrm{~A}$ bobby calf is a calf born onto a dairy farm that will be used for veal or dairy-beef instead of milking. There are many issues regarding the animal welfare of bobby calves, and for more information see Dairy Australia, "Bobby Calves," https://www.dairyaustralia.com.au/farm/animal-management/animal-welfare/ bobby-calves (accessed 2 February 2020).
} 
animals look to be well cared for. It was comments like this, said Irene, that remind them they are making a difference. The public perception of the farm, while not everything, was still vital for the function of the farm and the farmer. Through their descriptions of their farming practices, there was a sense of delight in what happens on the couple's land. These thoughts were noticeable when the couple took me around their farm after the interview was over. We drove along the road, Jake getting out to move some fence lines while Irene and I walked around saying hello to the cows. Watching the couple interact with their animals, I saw care, concern, annoyance, and genuine relationship.

In a final thought about sustainability, Jake explained that the concept of rest and celebration was one of the most important aspects for them. This means they do not do any extra work on Sundays, instead actively doing things that "feed their souls." As an owner-operated farm, Jake mentioned that this idea was vital:

[Farming] can become very self-consuming and it can go on and on. We had years of that. But even then we tried to have times of rest and times of work. But along with that is that sense of celebration, that sense of goodness on the farm. We have raised seven children on this farm, we have paid off a lot of our mortgage on this farm, we have been self employed and been able to make our own choices on this farm. We are able to choose to do things in this beautiful environment. To be able to sit back and celebrate that, rather than just grizzling about the difficulty of it, I would like to think that Christianity informs that, because it is a gift in many ways.

Farming is multifaceted and the farmer must be knowledgable in all aspects of farm life. Both Jake and Irene found it important to open the farm up to others, to showcase the complexity of farming, to share in its goodness, and to be generous with what they are stewarding. They have had foster kids, international students, and other visiting people stay and live with them. As Irene said, "Let them see the farm, and let them see faith!" They find it important to be generous with what they have been given, rather than being defensive and unwelcoming to outsiders. They feel they have nothing to hide and nothing to be ashamed about.

To end the interview, Jake and Irene both referred to a holistic combination of faith and farming, saying, "There seems to be a natural tendency for people to isolate their areas of life. This seems to be the natural way, but it is highly artificial. Our faith should inform all areas of 
our life. That is the theory, but we do have to work at making that actually happen." The couple desired to have faith to encompass all of life, although they did realize that practically this was easier said than done. From homeschooling together to farming together to living together, there was no segregation in the life of Jake and Irene's family. Sustainability in-part means living in collaboration with faith and farming, seeing the celebration that is in both their farming and their Christianity.

\section{The Problematic Nature of Sustainable Agriculture}

As seen from these interviews, the concept of sustainability is not singular in definition. It is the triple-bottom line focus of economics, social interaction, and environmental care. It is the addition of a spiritual bottom line as Christianity intertwines with the farming profession. It is being mindful towards the needs of the entire farming family. It is caring for the farm while still holding onto it with a light grasp. It is patience, persistence, and trial and error. It is being faithful to the creation God has made, while still being practical and pragmatic about what this care looks like in a agricultural setting.

While sustainability is an important topic, definitions of sustainability are permeated with enduring tensions. These definitions are also highly problematic, filled with ambiguity, diversity, and contestation. The couples described in this chapter hold views of bettering the farm through sustainable practices steeped in a belief that the farm and all it held was good. By looking at the interviews of Carl and McKenzie and Jake and Irene, it is clear that there are farmers desiring to utilize their faiths to better live with the land, animals, and community they are connected with. As McKenzie said, “This is not our business, it is God's business.” A part of leaving the land better than before and a part of holistically practicing agriculture sustainability is to remember Whose farm it ultimately is. Sustainability is a faith matter, but in different ways for different people. Within the case studies explained in this chapter, sustainable agriculture practices relate more directly to Christianity. However, in the following chapters I will examine how the idea of sustainability relates to other aspects of the farm. Sustainability as a faith matter relates to issues of community and land and place as well. 


\section{Chapter Two - Community}

In the previous chapter, I addressed the way in which sustainability relates to the farmers' understandings of agriculture and Christianity. As seen, the definition of sustainability carries with it a practicality that is influenced by the husband and wife relationship, as well as the people around the family and their farm. There is also a sense of goodness within a sustainable farming lifestyle, as the farm is often seen as a gift from God. While the farmers did not all share a common worldview or a common theological imagination, there was a distinct language with which they described sustainability as functioning with and on their land. This distinct language was especially evident through the idea of community as part of sustainability. While I wanted to talk environmental sustainability and farmers' sustainable agriculture practices, the people I interviewed continued to talk about community. This was, at first, extremely frustrating, as I felt I was not progressing my research. However, I began to wonder what it would be like if I took the frame they were giving me instead of trying to impose my frame on them. What can we learn about sustainability on New Zealand farms and its relation to Christianity if these conversations about the importance of community are taken seriously? All of the farmers I interviewed spoke about their communities, even though the topic was not included in the four main questions I asked during the interviews. Sustainability on the farm, as well as Christianity on the farm, does not act in isolation. Farmers live within tight knit communities that help sustain them and give them a reason to continue on that is not solely based upon the economics of farming.

The land is a space of relationality, one that includes church congregations, neighbors, families, business boards, missions organizations, social clubs, and mental health support systems. All of the farmers I spoke with alluded to understanding that the farm was not just their business. It was also a direct way to engage with their communities locally, nationally, and globally. The degree to which the conversation revolved around questions of community during an interview focused on sustainability was striking, pointing to an association between the two in the farmers' minds. The question then becomes where community belongs in the discussion on sustainable agriculture.

Over the course of my fieldwork around the Waikato and Nelson/Golden Bay, I became acquainted both with individuals and their wider communities, as everyone I spoke with knew 
others I was interviewing, often putting me in touch with their friends and family. I found myself in the midst of a vast web of interconnected communities, brought together by their farming and their Christianity. These communities were vital to the farmers' understandings of themselves, their land, their animals, their faith, their farms, and ultimately their practices of sustainability.

\section{The Necessity of Community In New Zealand to Sustain Farmers}

As previously mentioned, one of the few scholarly sources I found to give insight to rural New Zealand and the role faith played was through the writing of Robyn McPhail, a rural Presbyterian minister in New Zealand. She writes about the integral part that community plays in rural life, saying,

As individuals and households, rural people cannot choose to live in isolation from other people and although neighbors may live more than a stone's throw away, they can be closer in reality than town neighbors ... Good relationships with other people, like a good relationship with the land, are the recognized foundation of a successful and healthy existence. Rural common sense says that, like the land, other people can be dealt with more effectively when one works with them and not against them. ${ }^{41}$

Due to physical isolation, the importance of community is accentuated. Community is a vital element of sustainability for farmers and their families. Farming, and in turn sustainable agricultural practices, not only includes the land and animals, it includes the people. John Ikerd explains that sustainable agriculture must be in harmony with the community, "since people are a part of nature, with a basic nature of their own ... A sustainable agriculture must be in harmony with our nature of being human."42

One such avenue by which rural families are able to come together is through church, a weekly opportunity for engaging in communal relationships. Farming is a profession that requires intense dedication, as life can be overtaken by work and farmers can become consumed by all that must be done. The opportunity to leave and be with others is integral and necessary to the health of the farmer, the family, and the farm itself. According to McPhail, the respect for church communities in rural New Zealand feeds into the public community sphere. Whether

${ }^{41}$ Robyn McPhail, "Rural Spirituality" in Land and Place: Spiritualities from Aotearoa New Zealand, ed. Helen Bergin and Susan Smith (Auckland, NZ: Accent Publications, 2004), 121.

42 John E. Ikerd, Crisis \& Opportunity (University of Nebraska Press, 2008) 77. 
Christian or not, farming communities are steeped in the moral and ethical aspects of the Christian faith. McPhail describes these morals, saying, "The outflow of faith into behavior, identifiable as qualities like honesty, integrity and kindness, continues to provide the core of rural values. It is the culture that rural communities are working hard to retain in the face of the increasing urban cross-fertilization that comes within greater mobility and transience." 43 She sees church as culture-creating and culture-holding.

However, based upon many of my interviews, there are two meanings of church: the idealistic vision of the church being the main provider of supportive community and the realistic vision of the positives and negatives of a religious institution functioning within a space. The following interviews often rarely mention, if at all, the presence of the church within sustainability dialogue. While all of the farmers I interviewed considered themselves to be Christians, their relationship with church was often a cause of friction. McPhail writes, "The question is whether it is normal and unavoidable, for spirituality and business, faith and work, to reside in separate compartments of life, each with their own goals and guidelines and a matter of personal preference how much each features in an individual's life."44 This exact tension was felt in the interviews I conducted, as farmers tried to identify as both farmers and Christians, sometimes successfully combining the two, but oftentimes resorting to one or the other depending on their current situation.

When speaking to farmers about their sustainable agriculture practices, questions should be asked concerning the sustainability of the communities they are a part of, for a lack of community can cause difficulties within daily farm practices. When looking at sustainability from the perspective of New Zealand farmers, attention must therefore be given towards the community they are a part of and how they interact with this social dynamic of life. Robyn McPhail describes the positive relationality of rural spaces, saying, "The other arguably spiritual aspect that is central to rural life is the importance of the community. Pākehā rural people take pride in forming a close-knit and supportive community, with friendliness the experience and

\footnotetext{
43 Robyn McPhail, "Rural Spirituality" in Land and Place: Spiritualities from Aotearoa New Zealand, ed. Helen Bergin and Susan Smith (Auckland, NZ: Accent Publications, 2004), 118

${ }^{44}$ McPhail, "Rural Spirituality," 118.
} 
expectation in contact between people and greetings with a word or a wave so much standard practice that they are noteworthy in their absence." 45 However, not all of the farmers I met with had positive relationships with their community, this influencing and impacting their view of farming and of people in general. A distrust of others, and isolation on the farm, tended to be a result of an unsupportive community.

The following case studies showcase the value of incorporating community into conversations of sustainability for the farms and the farmers. I have chosen three couples to focus on within this chapter, as the ways in which they speak about community vary. These differences relate to both their understanding of farming practices and Christianity. Beginning with Fletcher and Joanie, I examine the utilization of the farm as a means to interact, support, and minister to the people surrounding the farmer. I then introduce Edward and Ruthie, who understand sustainability of the farm as directly correlating to the sustainability of people. Finally, I end with Martin, Katherine, and their son Paul, two generations of dairy farmers who see community in relation to their farming practices differently to each other.

\section{People are the Reason and Farming is the Means}

When the conversation around sustainability turned to community, the farmers I met with went one of two directions: their farm was the basis for their community, or their farm was a vehicle with which to cultivate outside community. These two understandings differed in that one saw the farm as being the focal point of their community engagement while the other seemed to see the farm as simply a means to engaging with the greater community. The first farming couple I met with that spoke to the primacy of community, even over the function of the farm, Fletcher and Joanie were located outside of Raglan on a one hundred acre dairy farm. Upon arrival, I was welcomed inside for a tour of the current house renovations, expressing their ease and enjoyment at having people in their space. There was no need to prove myself like in some other interviews. Instead, I was immediately treated as a welcomed guest, warmly told to sit

\footnotetext{
45 Robyn McPhail, "Rural Spirituality" in Land and Place: Spiritualities from Aotearoa New Zealand, ed. Helen Bergin and Susan Smith (Auckland, NZ: Accent Publications, 2004), 120.
} 
down at the dining room table covered with farm office work, a hot cup of coffee thrust into my cold hands.

Born and raised in the area, Fletcher came from what he described as "a strong Christian background" which included being able to trace his ancestry back to the Reverend James Wallace, the first European to settle in Raglan. Fletcher was brought up Anglican, but now attends Surfside, the local Assembly of God church. Joanie grew up in Australia, becoming a Christian when she was nine years old. She met Fletcher when she was seventeen and married him when she was nineteen. With no initial interest in farming, the couple worked for Youth with a Mission for ten years, both in Australia and in the States. Their background, therefore, was not in farming but rather in community missions work.

It was not until 1999 that they moved to New Zealand to help Fletcher's dad on the farm, leasing another 200 acres and milking approximately 300 cows. While not planning on staying long, the couple soon had a young family and felt that the farm would be a good place to raise children. Once they moved onto the farm, they quickly decided to progress to share milking. In 2004, they bought the land and took over the operation, and are now currently in the process of purchasing another 200 acres to make their farm more viable.

At the start of 2008, a few things happened that caused a major reconstruction of how the family was farming. A large drought was experienced through the entire Waikato region, causing the farm to lose $50 \%$ of its production. Fletcher's mother also passed away. The family had to deal with grief from her death alongside tremendous pressure from the drought. Joanie noted that it was during this difficult time that "We really surrendered the farm to God and that is when [Fletcher] had quite a good revelation." In the midst of hardship and pain, Fletcher explained how the arrival of this revelation was seen as a gift from God:

You just feel like a bit of a failure because you aren't hitting targets and [you aren't] able to care for your animals like you want to, so it's quite hard. You start taking all of this upon yourself. I really felt God say to me during this time, "You are just the caretaker of the land that I have given you. You are just the caretaker of the business I have given you. Everything that you have comes from Me. I am the source, and it is not anything else." 
This experience caused a shift in Fletcher's thinking, as he came to realize that "all [God] required of me was to be a good steward and to do my best with what I had. The rest was up to Him." A huge burden was taken off Fletcher's shoulders, giving him the ability to let go of the uncontrollable. His response to this revelation was, “Actually, that's right. God, this is all Your's and if You have other plans and You are leading us into another way, maybe I am too pig-headed and I can't see it and You have to bring it all down."

Through this experience, Fletcher was reassured that God, not the success level of his farming business, was "the bottom line." This was a direct commentary on the traditional triplebottom line business structure discussed in Chapter One. If all things come from God, then what he has is not based on his farming performance; rather it is because God Himself is good. This insight changed the way Fletcher viewed farming. It became less about profit and productivity and more about the journey, the people, and the business. God had calmed Fletcher and Joanie's anxieties over their control of the farm. This calming was directed towards their desire to use the farm to interact with other people, and there was not much conversation around how the experience had changed agricultural treatment of the land and animals on the farm.

Fletcher explained that this revelation was the reason the family had not moved to a better production location, choosing instead to decrease the size of their milking herds from 350 to 285 cows, along with cropping $10 \%$ of their land with summer feed so they could be more self-sufficient. Fletcher and Joanie are connected to this area and to their church, thus choosing to decrease their farm in order to run it more sustainably where it is, rather than move and lose their community connections. This, while echoing the couple's sentiments regarding people being their primary focus, seemed an odd thing to say when Fletcher and Joanie are also trying to expand their land holdings. Fletcher understood the drought and his mother's death as God "bringing it all down" in order to reorientate his farming focus from meeting the bottom line to helping the farming community. This story expressed an understanding of God purposely bringing pain and hardship into the family's life in order to initiate change, and, to Fletcher, a direct correlation between his personal faith and his new farming focus. Through this story, it can be seen that God, being ultimately in charge, changed the course of the couple's lives and, with it, the life of the farm. 
Fletcher and Joanie's background in missions, and the fact that the couple had no initial desire to farm at the beginning of their marriage, helped foreground their relationally-focused goals such that the farm was understood as a vehicle to meet and sustain community. Due to this relational focus in their farming, Fletcher decided to sit on multiple boards and councils that have helped to connect him with other people in both the farming community and the larger New Zealand community. He is on the Fonterra Shareholders' Council representing farmers in the Waikato West, which has opened up many opportunities to come alongside other farmers and be a leader within the industry. He also serves on Beef and Lamb's farmer council. ${ }^{46}$

As Fletcher noted, often farmers can become consumed with their issues and "you just need someone to lift your eyes up. It's really just God's principles saying 'Hey, together we can do this, you aren't alone.'" Pressures from the government, larger farming cooperations, and unpredictable weather are just a few stresses that farmers are faced with, and they need a safe space to talk about their anxieties. Fletcher sees his position on all of these committees as important, for "agriculture really needs leaders at the moment" and "I think often there is a lack of leaders who see it 'God's way."' Listening to him speak about his position in the community, I could tell that even though Fletcher and Joanie no longer work for a mission's organization, the way in which they conduct their life is still follows a missional approach. Their "mission for Christ" is now within the New Zealand farming community, rather than overseas.

Christianity has thus provided Fletcher and Joanie with a perspective, a system of values, and a structure of "proper" leadership and pastoral care. Fletcher explained how his life purpose comes from Micah 6:8 - "Act justly, love mercy, walk humbly" - and it is this verse that causes him to interact with people the way he does and why he puts such an emphasis on caring about

\footnotetext{
${ }^{46}$ See Beef + Lamb NZ, "Beef + Lamb NZ’s Farmer Councils," https://beeflambnz.com/your-levies-atwork/beef-lamb-new-zealand-farmer-councils (accessed 30 January 2020); Fonterra, "Shareholders' Council," https://www.fonterra.com/nz/en/about/governance/shareholders-council.html (accessed 30 January 2020).
} 
the sustainability of the farming community. ${ }^{47}$ According to Fletcher and Joanie, while there are conversations happening in the secular, corporate world about putting people first and serving them above all else, all of these being "Godly principles," there is still a large need for God to be included in the conversations. There was no further explanation as to what including God would bring, but Fletcher, through his position on various committees, sees himself as a person who can do this. He has the opportunity to talk to those who are outside of the "farming world," providing a space for others to learn and understand farmers, as well as see his Christianity. Fletcher is able to act as a bridge between farmers and the greater public, telling others, "Hey we are in this together. We need to find solutions. It can only come through collaboration and people coming alongside and working together, understanding each other and moving forward." If there is a divide and a misunderstanding between the rural community and the urban community, something must be done to bring them together, and Fletcher sees this as part of his combined farming and Christian vocation.

Embodying one's faith, according to Fletcher, means being a voice for farmers: "To me, this is how I see my faith [as] working in this industry and working with challenges ... like environmental, ... rather than just throwing stones at one another. It's just [finding] that balance and having those conversations." Fletcher explained to me that once you sit down with people and begin to have conversations about farming, especially dairy farming, giving examples of why all dairy is not "dirty dairy," greater understanding can be facilitated. 48 People need to talk to one another, realizing that "you can't have a blanket rule assuming that all farms are the same." There is a practicality in becoming completely sustainable and this must be acknowledged. By personally meeting with various groups in the "urban sector," Fletcher said

47 Micah 6:8 says, "He has told you, O man, what is good; and what does the Lord require of you but to do justice, and to love kindness, and to walk humbly with your God?" Fletcher was not the only farmer to mention these specific biblical passages when talking about how faith related to their farming practices. In Chapter Three, I mention Ash and Caroline who speak about the verse as a guiding factor for how they should relate to the world around them. In this thesis, all biblical quotations are from the English Standard Version (Good News Publishers, 2001).

48 The phrase "dirty dairy" speaks to the environmental damage that the dairy industry in New Zealand has caused, as well as the concerns around animal cruelty. See Jasmijn de Boo, "New Zealand's Dirty Dairy," https://www.huffpost.com/entry/new-zealands-dirty-dairy_b_14717214 (accessed 3 November 2019). 
others are able to see him as a person, rather than simply an industry group. He explained that the majority of farmers want to farm more sustainably but simply lack the tools and knowledge to do so. People want someone to blame and farmers are the perfect candidate, but farmers continue to stick to what they know because they are afraid of change and the unknown. All that Fletcher asks "is for a balanced conversation, even with climate and [environmental issues]. We just really need to apply some critical thinking and ... have a really good look at it." All aspects of farming must be taken into account: the land, the animals, the community, and even spirituality. The "balanced conversation" Fletcher spoke of recognized the ambiguous and often problematic definition of sustainability within the farming profession.

Joanie expressed admiration towards Fletcher and his involvement with other things outside of the farm. He is a hope, a support, and an influence to others, for, "How do people [farm] without God?" While farming can be a stressful profession, Joanie has assurance through her faith that things will end up alright. She expressed this notion, saying, "I never worry about anything (well, overall) ... It's Your's God. [I] keep coming back to that surrender and ... to that assurance ... so I think God significantly influences the way we do life and the way we do farming." This directly correlated to the earlier story of God "bringing it all down," the family having to reevaluate what was important to them within their business and their livelihood. However, like before, this comment was directed towards the couple's relationship with other people, rather than their relationship with the farm.

When I asked the couple about sustainability, Fletcher told me that "being sustainable for us [means] to be able to do what we like to do, which is being involved in other things like the Fonterra Shareholders' Counsel and TearFund work with dairy development." In this understanding of sustainability, Fletcher expressed a more of a focused perspective on himself, his family, and his community, rather than on his farm and the land and animals that were a part of the operation. Fletcher spoke about his holistic understanding of sustainability, saying, When I think sustainability, I think economics. I think social. I think environment ... You have to be able to sustain your family and your workers and the community. There are a lot of factors involved in it and it needs to be a holistic view ... You can't take things in isolation, you need to look at it as a whole. [This is] why collaboration is so key, because 
you need to [combine] all these areas to get the best result for everyone, which at times means compromising to come up with the best solution.

Fletcher's comment that being sustainable means being able to "do what we like to do" indicated how much community meant to the family, ultimately meaning more than the farm. While not directly commenting on this, it was evident by the state of the property, which was tidy but not in pristine shape. Fletcher was conscious that aspects of the farming operation were being overlooked. He told me that his busy schedule off the farm takes his focus away from the farm itself; things that need to get done can often be put to the side, a habit that he realized needed to change. Community sustainability held a greater importance than the sustainability of the farm itself. Fletcher's holistic definition of sustainability had less to do with the particular environmental practices and everything to do with the people involved in the practices. Fletcher and Joanie did mention their various sustainable agricultural decisions, such as the cleanliness of their waterways, once-a-day milking, and reducing their herd size. However, the environmental side of sustainability was not given nearly as much time as the community side. My interview with Fletcher and Joanie was an example of seeing farming less as a business or a way to work with land and animals, and more as a way to connect with other people. They were not alone in this view of the farm as mission-focused, as other farmers I met with after them spoke of the same ideas. The farm was important, for it was their business and the way in which their family was able to survive, but it served the greater purpose of showing God to others and supporting people who might otherwise be overlooked.

\section{Living in Harmony with Land and People}

While Fletcher and Joanie expressed in their interview community sustainability being of greater importance than the sustainability of their agricultural practices, Edward and Ruthie conveyed a more balanced understanding of being both farmers and Christians living in the midst of others. Flying into Nelson on a crisp day in late June, I drove over Takaka Hill to spend a few nights with the couple, whom I had gotten in touch with through a friend of a friend. I made my way onto the gravel road that led to their small farm, where I was met by a couple deep into their eighties. While they have six children, two of whom live with their families on the farm and are 
now in charge of managing the business, Edward and Ruthie still take care of all the chickens, a pet sheep, their three dairy cows, and property maintenance. I was immediately swept up in helping them do various chores, meeting the dogs and jumping on the four-wheeler with Marie, one of the children who has taken over the farm. We went out to the main paddock, feeding hay to their beef cows and climbing persimmon trees, talking about regenerative farming and how to sell meat without packaging it in plastic while we waited for one of the watering troughs to fill up from the hose. 49 According to Marie, it was not the most time-efficient farming set-up, but they were working on it. She wanted to farm in a way that was kind to the land and the animals and this currently meant spending longer hours doing things correctly.

I stayed out in the little side house, a motel-style building consisting of three small bedrooms and a shared bathroom. It was modest but perfect for hosting guests on the farm, the bedrooms filled with books, quilted blankets, hot water bottles, and even a little crib if a baby happened to be present. This set-up showed evidence to the openness of having guests stay for long amounts of time, as did the casual nature with which the couple interacted with me and gave me access to their home. Their son John, who leads an international student ministry in Nelson, joined us for dinner along with an American in his twenties who had been staying with him. We finished the night drinking tea with fresh milk from their cows while I interviewed the couple.

The owners of a 200 hectare sheep and beef farm, Edward took time to list off all the other assets the farm they lived on had to offer: firewood, timber, scenery, regenerating bush, and land used for honey bees. The couple carried intimate knowledge about everything their farm had to offer, as well as how it functioned. Originally his parents' property, Edward arrived with his family in 1939 at the age of six. His parents were dairy farmers, milking twenty-five cows along with keeping a few hundred sheep, the prices for wool being high in the 1940s and 1950s. Edward's parents took over the farm during the depression as well as during a particularly bad drought, and the land was so dry that that the hills were white. In the farm's beginnings they used

\footnotetext{
${ }^{49}$ Regenerative farming describes "farming techniques and methods of land management that are designed to restore soil productivity by measures such as crop rotation, planting ground cover, protecting the surface with mulch, and reducing the input of synthetic chemicals and mechanical compassion." See Oxford Dictionary of Environment and Conservation, 3rd ed., s.v. "Regenerative Farming."
} 
to burn everything in order to grow grass, but Edward and Ruthie have been working to bring much of the native trees and plants back, as well as planting and fencing around the main creek to keep the animals out.

In terms of their faith background, Edward was born into an Anglican family in England. As he grew older, he consciously renewed his relationship with God on a personal level, "and the rest is history." Ruthie, growing up in Holland, had a different story. Her parents ended up leaving the church because "they were liberal" and when she met Edward she had to make a decision about her own understanding of Christianity. She came to the realization that unless she lived a Christian life, meaning "to be able to share and live like Jesus," that there was no hope for the world. In her words, "The future for the world was when Jesus says, 'I am the way the truth and the life.' That is how I sort of gave my life [to Him], and although there are often times when I don't agree with conservative Christianity, I always look back on the messages Jesus gave to be the light of the world. And that counts for your farming as well."

Ruthie became interested in farming after reading a book by British organic farmer Newman Turner, which described the benefits an organic way of living close to nature had on the land. Traveling to England to visit Turner's farm, she ended up meeting Edward, and began traveling around with him to meet various organic farmers. As Edward said later in the interview, "Within three weeks of living in England, ... I found myself at the annual meeting of the British Soil Association in London and I joined up and from there all sorts of things happened ... And then [Ruthie] turned up one day and she was looking for Newman Turner and I was already there. God works all things for good."

Inspired to approach farming with organic principles in mind, this including the minimal use of sprays, Ruthie pointed out that their farm is not certified organic, for it is difficult to practice fully if the farm is not naturally fertile. Edward interrupted Ruthie at this point, saying, 'I think, Love, it really is no excuse. We've been pragmatic about it. [It is an] ideal that we have never really stuck to." He followed this statement with a long sermon about soil biology and how 
fertilizers can be used that are better for the ground, even if they are not fully organic. ${ }^{50} \mathrm{In}$ Edward's opinion, farmers must learn what is good for the soil, becoming more knowledgable about the science of their land. This dialogue between the couple further affirmed my growing belief of sustainability being a constant tension between pragmatism and other potential values and desires held by the farmer.

The purpose of a farmer, according to Edward and Ruthie, is to help nature work well. A farmer should "try to work in harmony with nature's laws," optimizing the preconditions for nature to do "what She does best to prepare the fruits of life for the plants. There is water and there is drainage and all those things, but we are sort of limited by the amount of money we have got to spend." As Edward was speaking about the limitations that occur based on financial hardship, he also mentioned that this does not stop them from trying to be as kind to the land as they can be. His usage of "She" when referring to the land expressed his understanding of the land as having a personhood. Currently, the farm focuses primarily on rotational grazing, also working to be sustainable and healthy through the use of non-toxic sprays. Farming is an observational process, one that the couple and their children continue to patiently learn about.

Alongside this conversation about treating the land with respect, Edward mentioned the practice of fallow farming and its biblical basis:

[The Jews] had this rule a long time ago, that [the land they had] would be laid fallow and it wouldn't be plowed. It would just have its wild growth that wouldn't be harvested, so that it provided a new biodiversity. So people knew to work with what God had created, and I think that is very beautiful. We don't [follow] this fallow idea, because it looks so wasteful. But it is very good for the land. [Our children] are trying to do it by not grazing [the land] to the ground so there is always something left growing.

The topic of fallow farming led into a conversation regarding what it meant to be a Christian farmer. According to Edward, all people have some sort of ethical value system:

There is always a cause and effect, as far as our Christianity is concerned as farmers. As far as our religion, for most people it is an unconscious connection, but it is there inside of us ... [There are] consequences if we do or don't do such and such on the land, [and]

\footnotetext{
${ }^{50}$ I use the word "sermon" to describe the way in which Edward spoke to me because it contained all the characteristics of a pastoral sermon. Likewise, I use this word because it describes Edward's history as a missionary in Australia. This was a fact that Ruthie briefly mentioned in our daily conversations, and I did not get much more detail into this stage of the couple's life.
} 
we observe what result it has ... Whether we like it or not, we do function physically on an economic level, like it pays or it doesn't pay in terms of money or in terms of the equivalent of money. [There are] a strong set of parameters or rules of guidelines in our religious writings ... like in the Bible under Moses the Jews were given guidelines on blessings and it included the land very much. There were instructions given to the Israelites of how to live and these are general guidelines that everyone has from God, but we need to be more focused on the teachings that are given for a blessed life (to put it one way) ... it is those principles that are for all times, like giving the land its shabbat.

There are rules, biblical or otherwise, for how to treat the land. Farmers, according to Edward, would be wise to pay attention to these rules. Ruthie then shared her thoughts on the importance of holding onto a biblical understanding of the land:

I am a biologist so I believe in evolution, but I always say that the important bit of the creation story is that after every verse it says "And God saw it was good." This is the important message - that the nature around us ... is good. And if it is good in God's sight then it means that we are meant to look after it. That it is precious. So I am very much a conservationist. I studied ecology and worked in nature reserves, and I very much feel that we should honor this in our farmer life. And, of course, on this farm we have all the beautiful bush that fortunately wasn't all taken way.

Edward continued on with Ruthie's initial thought, and after another long sermon on how biblical teachings can tie into the practices of agriculture, he concluded by saying that "It is all grace, and it all comes from God in the end. If any man lacks wisdom let him ask God who gives liberally ... In Him all things consist and have their being." Edward explained that the world is in the process of restoration, that God made everything "good," and therefore all of history has been a process of returning "to the perfect, to the beautiful, to the Godly." Farmers are able to aid the land in its returning to "the perfect."

During the interview, Edward asked his son John for his opinion regarding how his parents' Christianity and farming practices had impacted him and his siblings in their treatment of the land. John looked uncomfortable at being brought into the conversation but proceeded to share his thoughts, saying:

The Christian faith that mum and dad and my gran and grandad lived out, the way that they obviously cared for the land and used its resources, I think influenced me and my siblings, [as well as] many other people who come here to the farm. So even without them realizing it, I think that just living in a way that is sustainable, living simply and not wasting things, has been a value that has impacted [us] and it is evident. I know that it is 
something I have picked up from growing up [here, and this farm] is very much a part of my Christianity ... Because God created the world, and we value what He created and therefore we want to live in a way that cares for this creation and doesn't waste it.

Edward then asked his son what he thought the greatest limiting factor to healthy and sustainable farming was. John replied that it was our sin - the sin of Adam and Eve meant that farming is difficult and our selfishness controls us. Edward agreed with his son while also saying that, in his opinion, the greatest limiting factor to sustainability was the economic system "which makes us do things out of grim necessity. [This] compromises our ideals, especially in regards to farming. The agricultural sector's bottom line [is] for the provision of necessities for the family. [The economic system is a] selfish, man-developed [system] that we have, so it has good bits and bad bits." Edward's frustration with the economic aspect of sustainability was evident, placing the evils of the economic system on par with the sin of Adam and Eve. The forced pragmatism that the couple has had to farm under has rendered them unable to farm completely organically. The economic system in all its "selfish, man-developed" characteristics has hindered their ultimate desires for true sustainable agriculture.

After the interview was finished, not for lack of things that Edward and Ruthie had to say but more due to the fact that it was late and I was falling asleep, Ruthie grabbed my hand. She quietly asked if I might be able to interview her again the next night as she had not been able to share all her thoughts, given that Edward was a talker and continually interrupted her when she tried to speak. However, these were not rude interruptions. Rather, Edward had rarely been asked to share his thoughts on these matters, and he relished the chance to talk to them.

The next morning, as Ruthie and I were walking together to feed the chickens and milk the cows, she told me that if I was writing a thesis about sustainability and how Christianity influences such ideas, I really needed to include the social parts of their farm. To her, it was the social aspect of the farm that was the most important, this being what she had wanted to say to me in the interview the night before. In her opinion, community outreach, as well as bringing people onto the farm to stay and rest, was a very important focus. Farming is isolating at times and people need other people, as well as a space to take a break from life. This was a belief 
constantly put into practice on the farm. It was evident through the young Israeli couple with two small children who had been living for a year in a tiny house located on the farm. It was evident through the British couple I met who had been living on the farm for a few months and helping them build a movable "chook wagon." 51 It was evident through the in the way Edward and Ruthie had many lunch guests coming and going, both from the Takaka area as well as connected with John and his ministry in Nelson.

The following evening, Ruthie and I sat down after dinner with some fresh ginger tea, while Edward closed his eyes and listened in his chair by the fire. Ruthie then shared her thoughts on what she believed was important to her and Edward's particular farm. The idea of healing had been in their minds for a long time. Ruthie explained how in the Old Testament it says to heal the sick, to comfort the poor, and to make the blind see. 52 Realizing that hundreds of years before Jesus came to Earth this message of healing was already the message people were hearing had always been inspiring to her, and in her opinion was the reason for her Christianity and her overall life. The idea of healing, according to Ruthie, "is the big message that Jesus came to give. We are so privileged to live in such a beautiful place and therefore we feel like it is something that we must conserve and share with people." The farm is a space that can be used to help other people, something that can easily be combined with the couple's Christian faith. She quoted Micah 6:8, saying, "What does the Lord require of me, that I have justice and mercy and walk humbly." This is the same verse that Fletcher (as well as Ash in the following chapter) mentions in his interview. However, the way in which Fletcher and Ruthie reference the verse is quite different. Fletcher talks about Micah 6:8 as being his spiritual motto and the reason he feels led to be on so many different farming boards so that he might help other farmers. Ruthie, on the other hand, uses this verse as an explanation for the reason they wanted the farm to be an open space for people to come and heal. While both saw the verse as relating to their treatment of

\footnotetext{
51 An idea made popular by Joel Salatin, the "chook wagon," or mobile chicken coop, is a system that supports pastured poultry. The coop moves between cow grazing paddocks, chickens able to roam free and feed on pasture, while at the same time fertilizing the ground and aiding in growth of the area. See Mid-Atlantic Gardening, "Polyface Farms: Pigaerators and Eggmobiles," http:// midatlanticgardening.com/polyface-farms-pigaerators-and-eggmobiles/ (accessed 2 February 2020).

52 "The Spirit of the Lord GOD is upon me, because the LORD has anointed me to bring good news to the poor; he has sent me to bind up the brokenhearted, to proclaim liberty to the captives, and the opening of the prison to those who are bound ..." (Isaiah 61:1).
} 
people, Fletcher uses the verse as a way to justify a smaller focus on the farm and Ruthie uses the verse as a way to justify a greater focus on the farm. While Fletcher described Micah 6:8 as being the basis for his life's purpose, Ruthie quotes Micah 6:8 while speaking about being privileged to live in such a beautiful place. She uses the verse as a reason why they must conserve and share the land with others, even if this is a difficult battle at times.

Edward and Ruthie frequently have people stay, and their son John, through his work in Nelson, brings people to the farm as well. The structure of small-scale farming has given them the chance to meet the needs of those around them, as well as the ability to have more intimate relationships with the land, the animals, and the community. According to Ruthie, "We focused on the farming bit, but it was really the whole of life. Now you have these big corporations that buy up a bunch of land and have giant cow sheds and a roster, and there is no time for anyone else. Everything is mechanic ... and there is no room for anybody." The community focus has been lost in the farming business because it is all about bigger and better and less about the actual farmer. Little farms are being bought up by larger corporations, and this has been a great frustration to Ruthie. 53 She ended up writing a letter to the Prime Minister addressing the importance of small farmers and how it is unacceptable that they are being penalized when they are the ones who "shelter other people." Being a Christian, according to Ruthie, was about standing up for others, and this is what she does.

Listening to Ruthie speak, I could tell that she was equally passionate about land and people, both of these passions stemming from her Christian faith. This was a belief equally felt by Edward, who had expressed to me earlier how the whole of creation responds to our caring for it, and that if we give to both the land and to people, "it will be given unto you." 54 These thoughts expressed to me their belief that if farmers, and all humans for that matter, have a

\footnotetext{
53 Glen Herud, "Factory Farms are Killing Off Family Farms, but All is Not Lost," https:// www.stuff.co.nz/business/112442169/family-farms-going-out-of-business-but-smallscale-dairying-couldstill-be-the-future (accessed 23 May 2019).

54 This quote comes from Luke 6:37-38: "Judge not, and you will not be judged; condemn not, and you will not be condemned; forgive, and you will be forgiven; give, and it will be given to you. Good measure, pressed down, shaken together, running over, will be put into your lap. For with the measure you use it will be measured back to you."
} 
continuous dialogue with God, everything will fall into place. It is both about care of land and care of community. Sustainability is both ecological flourishing and community flourishing.

After my second interview with Ruthie, it was time for me to travel around the Golden Bay Area and talk to other farmers. I had lined up a few interviews, but unbeknownst to me, Edward had kindly called up some of his farming friends in the area that he knew were Christian. When I woke up on Tuesday morning and entered the kitchen, I was bombarded with a fullschedule for the day. These farmers that I was connected with were people Edward and Ruthie knew both from their local Church of Christ congregation and from Golden Bay being a small community. I spent three nights total with Edward and Ruthie, as well as one night on a return visit to Golden Bay.

\section{A Multi-Generational View of Community 55}

One important aspect of the conversation around community is recognizing that farming communities are often made up of a few integral families. The generational aspect of farming, children taking over their parents' profession, creates a unique structure between people. Having been given their contact information from Edward and Ruthie, I did not know what to expect in terms of my meeting with Martin and Katherine. Driving down a gravel road just outside the center of Takaka, surrounded by large square paddocks, milking stations, and rolling hills in the background, I arrived at the house and was greeted by Martin, a large and very friendly man, who welcomed me inside and introduced me to his wife Katherine, who was sitting on an oversized chair, knitting a large blanket. A cat rubbed itself against my feet as Martin told me he was not quite sure what I was wanting to talk with him about, but that Edward had called him up asking if he could meet with me and he thought it sounded alright. An hour later, Martin was still talking animatedly, with Katherine continuing to work on her blanket, interjecting every so often to quietly add her thoughts to the conversation.

\footnotetext{
55 I was able to interview both Martin and Katherine, and their son Paul, during two different trips to Golden Bay. Due to their relation to one another, I would like to write about the family as one singular case study, looking deeply at how the parents view sustainability and community compared to their son and his family.
} 
Growing up in Bainham, Martin lived there until moving to his current farm forty years ago after marrying Katherine. The two of them met while on an exchange trip, Katherine being from a farming family in Queensland, Australia. The couple originally owned four dairy farms in the area, but have since sold two of their farms to their sons and are currently in the process of selling land to the last son. They also have an adopted daughter who lives in Nelson, and while she is not interested in the farm, she does get a share of the profit. Presently, the farm is milking 700 cows on 250 hectares. Martin is no longer associated with the daily milking, employing three other workers that help his son, although he is still in charge of all the books. The farm also includes a 140 hectare block at the base of Takaka Hill, which is used to run bulls and beef cattle during the summer, as well as to graze dairy cows in the winter.

In terms of faith, Martin grew up in a Christian family, meeting in Bainham every Sunday at a church made up primarily of his extended family members. A small Church of Christ congregation, there were between ten and fifteen people in attendance each week. As generations came through, they all participated and helped lead the service, although they did have a traveling Anglican minister who would conduct a monthly service. Given that the church was lay-lead, there was a strong emphasis on singing, and prepared sermons and other readings were used as the morning message. At an early age, Martin was reading and praying in church, and by his early twenties was conducting communion and leading services. The church was a family affair, and it was seen as a vital part of the week. According to Martin, nothing was more important than Sunday church.

When Martin and Katherine moved down to Takaka, they continued to be a part of the local Church of Christ congregation in Golden Bay. However, they did not enjoy their time there, as there were certain aspects that the couple did not agree with, causing them to feel alienated and upset. Eventually the family moved to the Presbyterian church and have been there ever since, feeling welcome and becoming very involved within the church. Martin acts as an elder, a session clerk, the treasurer, and part of the welcoming committee with his wife. Currently there is a part-time pastor, which has helped to take some of the burden off of the locals who are busy with their farms and other jobs. 
Martin went on to explain the other pressing issue of being a part of a rural church - not only is it often up to the congregation to lead worship, but the congregation is not very big. The average age is $70+$ ("Most members feel younger than their actual age!"), and Martin explained that, "they are starting to drop off at the top, and fewer young people are coming in at the bottom." Due to this drop in church attendance, there has been talk of combining with other churches, although according to Martin "the spirit of cooperation in Golden Bay is not as strong as we wish it was, which is sad. We have tried to be welcoming to the other churches but it hasn't always been received with the same amount of positivity." While many of the church communities do not get along in Golden Bay, the Presbyterian and Anglican churches do get together once a month for worship. Martin has also been commissioned by the PCNZ to conduct communion, meaning the sacrament can still be administered even if a minister is not present. 56 Martin shared with me his thoughts on the relationship between his faith and his farming practices, saying,

I've always had a fairly strong commitment to the world in which I live and my particular part of it. I understand that I am just a custodian for a very short space in time and that if any of my family chooses to carry on, they will only be here for a short amount of time too. Then it will go to somebody else. But while it has been my responsibility, well then, I've sort of tried to be responsible about the way I look after it.

Like other farmers I interviewed, the tension between sustainability and financial limitations was an issue that Martin spoke in depth about. His faith causes him to see his profession as a response to the gifts God has given him, and he tries to not let money hinder his care and production of the land. In regards to the growing environmental rules and regulations around farming, he commented that in recent years he has planted around creeks and streams and fenced all his waterways off, these rules helping him to focus on the environmental impact of his dairy farm a bit more seriously than he might otherwise, which has been helpful. He also noted that while they used to try and utilize every last hectare of grass that they could, now in order to be as environmentally sustainable as they can, some are left to rest and regrow, a decision that protects the land as a whole.

${ }^{56}$ PCNZ stands for Presbyterian Church of Aotearoa New Zealand. 
Martin thought that most dairy farmers sought to treat their land and animals well, but he also noted that public perception is very important and more effort is needed to keep the farm looking good. This is one of the reasons that they have chosen to move away from cropping, as they felt uncomfortable about the undue detrimental effects the cows were suffering. ${ }^{57}$ While there might not be anything wrong with how the cows are being fed, it does not look good at all. As a Christian, Martin is also careful to set a good example to his children and his staff about animal treatment. Part of sustainability is to focus oenological flourishing and animal welfare.

A large purpose of the farm is not even the farm itself, but rather what happens off the farm. Katherine mentioned that her and some other women were making blankets for kids in Romania, this coming out of a trip to "rescue a child back in 1991." This child was their adopted daughter. In Katherine's opinion, their decision to adopt from Romania was “clearly a Christian response." They set up the operation of their farm in such a way that they could be away for six weeks to get their daughter. Things were not easy once she came to live on the farm, given that she had been neglected for the first three years of her life and it took considerable effort to have her in a position to begin school at five. According to Martin, "This was a Christian response to a need and we did not let our farm stop us from doing that. We found a way around the issue that we saw as being more important or equally important as the farm. [We] left other people in charge and trusted them to look after their assets and keep the cows milking and the money rolling in."

For Martin and Katherine, the farm was a vehicle to achieve other things in life, whether it be adopting their daughter, being the president of the local Lion's Club, or traveling. They understood the ability to get out into the community and help people who have found themselves in a tight spot as an extension of their Christian faith. While Martin and Katherine used to be involved in various farm organizations, they have since pulled back from those, now focusing

\footnotetext{
${ }^{57}$ Cropping is the agricultural practice of growing various types of crops such as swedes, turnips, lucerne, maize, fodder beet, chicory, plantain, kale, and cereal species. Farmers often graze these crops in the winter, when grass and other food sources are sparse. However, the practice of intensive winter grazing is an ongoing debate due to cows being seen standing, lying, and giving birth in muddy paddocks. These conditions are often unsustainable for both the animals and the surrounding environment. See Esther, Taunton, "Cows in Mud," https://www.stuff.co.nz/business/farming/114607024/cows-in-mud-newimages-stir-up-cropping-concerns-once-more (accessed 20 August 2019).
} 
primarily on the Lion's Club and church work. The couple lives a simple lifestyle so that they can put extra money into traveling and keeping in touch with family. In Martin and Katherine's opinion, the farm should not be all-consuming, leaving space for engagement in both the local and global community.

Two months later, I found myself back in Takaka, driving past Martin and Katherine’s farm to meet with their son Paul. A sixth-generation dairy farmer, he milked 250 cows once-aday on ninety three hectares. He gave me a background on the farm, explaining how he had been there for four years, he and his wife buying it from the larger family operation of 1,900 cows.

In terms of his faith, Paul was raised in the Presbyterian church, going about three times a month growing up, although they did not discuss Christianity outside of church except to say the blessing before meals. Having interviewed his parents previously, this was an interesting comment given that Martin and Katherine spoke at length about their passion and involvement with their church and in their Christianity. When he went to university, Paul stopped attending church. While he has stepped away from church engagement, Paul returned to Christianity through mental health issues that began a few years ago. He commented on this, saying,

When you have mental health issues, I guess you grasp for whatever you can. I definitely found my faith again, not in a practicing form, I guess, but more in a personal form in my own kind of studies and just bringing prayer back into my life. We certainly encourage our kids to be a part of it and they attend a youth group ... [since] we are not going to church, I want them to have some sort of understanding or education of [Christianity].

Paul's opinion of church was that it is not a necessity for the Christian faith, something that showcased his age, given that the older generations tended to think the two were hand-in-hand. However, he still believed Sunday should be a day of rest:

I am not sure if I am using the whole not going to church thing as an excuse or not, maybe it is because I have grown up with it, [and] I don't want to say church is a waste of time. But we are working so hard as a young family. We had three kids under three at the same time, so it was all go, that we actually used Sunday as our day off and we would go out and do something. We didn't go to church, but we did do something as a family. I saw this as something, in my view, that was more important than what I had grown up doing. 
Instead of simply following a ritualized Sunday church attendance, Paul found it more helpful and restful to spend time doing fun things with his family. This was different from this parents, who understood church to be a vital part of family and community life.

His severe depression and difficulties with mental health not only caused Paul to reaffirm his personal faith, it also pushed him to create a platform on social media to help other farmers feel more comfortable vocalizing their difficulties. The campaign, entitled \#yolofarming, has gained national attention, and it has connected Paul back to his family as well as to the greater farming community in New Zealand. Paul realized that farmers needed to come together and talk about their mental health if any of them were going to have a healthier and more sustainable lifestyle. To him, sustainability is "quite simple. It is being able to ensure that we can do the same thing we are doing today in the future." He has taken steps to be more sustainable in all areas of the farm, saying,

We have changed our farming practices quite a lot because of this. When we first started three years ago, we had 360 cows on the farm. Now we only have 250 , and the next year we could potentially have even less. We were bringing in a lot of supplemental feed and pushing the farm really hard. While we were profitable, it was also very hard on the farm and hard on the land and hard on the cows and hard on the people. We were just constantly under pressure. We [now] try to run our farm on a very simplistic system, so we are constantly analyzing [numbers] and decided to drop the cows back.

According to Paul, making money can blind farmers to their harsh treatment of the land, the animals, the workers, and themselves. Therefore, sustainability is impart seen as a critique on capitalist greed. Another reason that they decided to cut back on the pressures they were placing upon themselves and the farm had to do with Paul's mental health. Sustainability was lifestyle continuity. The family realized that part of the reason things were so difficult was because they were not proud of their farming practices:

As part of my journey with the yolo farming stuff, there are five mental health pillars: gratitude, connection, learning, giving, and normally the other one is being active. Because I am a farmer and also because I have three boys who keep me active, I have cancelled that last one out and as our pillars we have chucked in pride ... being proud of what we do. We weren't really proud of what we were doing and the way in which we were producing, so we changed the way we were doing things. You can't tell your own story and show people what you are doing if you aren't proud of it. 
Paul's explanation of the five pillars reminded me of the triple bottom line, both formats giving structure and accountability to the ways in which a farmer treats their farm, their land, their animals, their workers, and themselves.

When I asked Paul about whether or not his faith impacted how he farms, he paused for a long time. Finally, he answered me, saying,

I would say yes. I wouldn't say like an affirmative yes, but it is definitely in the background there. I think that my faith is a part of who I am as a person and as a person I want to farm sustainably. So when I am making a decision about how to look after the land, I am not looking after the land for God or anything like that. I am looking after the land because it is the right thing to do.

To Paul, his faith is a part of who he is, as is wanting to be sustainable in his farming practices, and he has often thought about this question. In fact, he recently put up a poll on social media asking other farmers whether or not their Christianity affected their farming practices. This was one of the reasons Paul had been so intrigued with my studies and had wanted to talk to me to see what I had found. He had anticipated the response to be about 50/50, when in reality only 5\% of the farmers who responded said that their faith impacted their farming. Paul shared with me the reason he asked this question in the first place:

[It must have] been last spring, because we had a staff member one time who was a deeply religious guy from Argentina. I admire him because he was one of those guys who was just so into [his faith]. If I was going to fully get into [Christianity] I would want to be like him. When he had a sick cow he would be out praying with it and have his family out there with it and using his faith as much as he could. He just lived and breathed and bled it. And then I had one of my friends who was the best man at my wedding. He didn't have any faith. He had a downer cow on his farm and one day [the Argentinian man's] cow got up, but the other guy's cow didn't. And so this one friend of mine who isn't practicing said something like, "It just isn't fair! He has his family there, he's got his dad there, and then he has the big fella upstairs looking after the cow also."

Paul had a downer cow one day, and began to think about this farmer praying for his cow, wondering if other farmers did this as well.58 He told me that, "When you spend a lot of time on

\footnotetext{
${ }^{58}$ A downer cow is "one that is sitting or lying on the ground and unable to get up." There are many reasons for this to happen, but downer cows are most common around calving season. See DairyNZ, "Down Cows," https://www.dairynz.co.nz/animal/cow-health/down-cows/ (accessed 20 August 2019).
} 
the farm and you are farming alone, and when you are thinking to yourself or talking to yourself, are you then talking to yourself or are you talking to God ... who are you talking to? I kinda had these thoughts in my head."

This story expressed Paul's history, growing up in a Christian family and now trying to understand what it means for him personally. He actively questioned the purpose of faith on the farm and whether or not it is a key part to the lives of farmers who believe in God. Paul was the only farmer I had met who had asked others about their faith impacting their farming practices, and I found this especially interesting since he himself has a nontraditional Christian faith, meaning he does not see active church participation as a vital part of one's faith journey and community engagement.

The interview ended with Paul giving his thoughts on rural Christianity and the church, something he saw as changing with the younger generation. According to Paul,

I think we probably lose a lot, particularly in the rural sector, with not having a Christianbased society. I don't wanna say that we are moving away from it more in the agricultural community - I would say it is probably that way in every community - but yeah just the openness and understanding and forgiveness [instead of] profitability and greed taking over too much. This is certainly affecting our communities ... I think the other thing from the church side of things, I am a do-er sort of person and I struggled with that in the church and the donations that I give of my money and my time I kinda just want to be able to control them myself and get the most benefit out of them. Is this a selfish opinion, I don't know, but this is kinda where my faith is at the moment.

Paul's comments about losing "a lot" by moving away from a Christian-based society, was interesting given that he himself does not adhere to regular attend church. His thoughts expressed a tension between living a semi-secular life while also keeping to the morals and values taught to him through Christianity. Unlike his parents, Paul's views expressed an understanding of community that focused on other farmers his age, rather than focusing on a certain faith tradition or worldview understanding. 


\section{The Importance of Community}

Robyn McPhail writes about communities in rural spaces, saying, "Rural life is unavoidably life-in-context ... 'No-one is an island' is a practical reality: there is no rural life in detachment from others - other humans or the land. If spirituality is an expression of relationally and connectedness, which I believe it is, then rural existence is inescapably spiritual." 59 As seen in the above interviews, this statement is deeply true. Community is, for better or worse, rooted within the Christianity that the couples I met with believe. It is also less than idyllic. Community is messy and complicated, paralleling the tensions found in being a sustainable farmer. Wendell Berry describes the farming community as "a complex local culture," and my interviews show this in a variety of ways. ${ }^{60}$ Being welcomed into the homes, and in turn the communities, of the farmers I met with in my fieldwork areas, I was given direct insight into the good and the bad of what living in rural spaces means. Not only do farmers feel isolated from the wider nation as a whole, they can become isolated from each other, this isolation causing distrust, ignorance, pain, and ill-health.

It was not until I began listening to the way in which farmers spoke about their community during my questions that I saw the role it played for them in the definition of sustainability. If community is needed in order to sustain the farmer, attention must be given to this. Whether it is urban acknowledgement of rural spaces and rural people, churches supporting farmers and their families, or neighbors helping neighbors, as Ikerd notes, "Neither land nor people can be sustaining or sustained unless they are given the attention, care, affection, and love that comes only from lives lived in harmony - among people and between people and nature."61 Community is the support system with which sustainable agriculture can best be created.

\footnotetext{
${ }^{59}$ Robyn McPhail, "Rural Spirituality" in Land and Place: Spiritualities from Aotearoa New Zealand, ed. Helen Bergin and Susan Smith (Auckland, NZ: Accent Publications, 2004), 123.

60 Wendell Berry, The World-Ending Fire (Penguin Books, 2017), 205.

${ }^{61}$ John E. Ikerd, Crisis \& Opportunity (University of Nebraska Press, 2008), 80.
} 


\section{Chapter Three - Land and Place}

I have now argued that definitions of sustainability are permeated with enduring tensions and are interwoven into the community that the farmer and their family resides in. In this chapter, I will examine how these tensions are navigated as farmers relate to the land, examining how a farmer's Christian faith might influence this navigation. Within this, it becomes important to understand the way farmers relate to the land around them. I will begin with a background on Christian Agrarianism and the ways in which Christian writers have explored topics of sustainable agriculture in relation to the land. I will then move to the New Zealand farmers I interviewed, focusing on three case studies to analyze how they interact with their land as farmers and as Christians. Through these, I propose that the way in which Christian farmers relate to their farm can often be filled with spiritual experiences relating to land and place.

\section{A Christian Agrarian Understanding}

Christian Agrarians argue that their view of the land derives from Christian scripture and its emphasis on creation care, having an intimate and knowledgable relationship with a particular place and caring for the land because it is a part of God's creation. Writer, farmer, and theologian Kyle T. Kramer describes his relationship to the land, saying,

Through taking up a 'vocation of location,' I began to see the land itself as a sort of spouse - although the commitment, to be sure, more resembled an arranged marriage. I had paid my dowry and signed a contract, and now we were getting to know each other and figuring out how to live with one another. As I got to know the farm better, however, I felt a real shift in my thinking, one from ownership and an abstract ideal of responsibility to a deeper, more personal, even tender connection. I began to care about, not just to care for, this particular piece of land. ${ }^{62}$

It is through an understanding of place, an understanding of the spirituality that comes with knowing a place, that these writers see the developing of a full regard for the manner in which humans care for the land they are on and the significance of using sustainable agricultural practices.

\footnotetext{
${ }^{62}$ Kyle T. Kramer, A Time to Plant (Ava Maria Press, 2001), 65.
} 
Wendell Berry speaks towards this importance of knowing the land in his 1970 essay “Think Little." In a society desiring cheap and easy access to agricultural goods, pressure is applied to the farmer to work and produce a greater amount than is often sustainable: "his margin of profit is small, his hours are long; his outlays for land and equipment and the expenses of maintenance and operation are growing rapidly greater; he cannot compete with industry for labor; he is being forced more and more to depend on the use of destructive chemicals and on the wasteful methods of haste. As a class, farmers are one of the despised minorities." 63 According to Berry, the grounded understanding and relationship to the land will soon be lost as the farmer grows older and their children move into urban ares.

These writers, while speaking with a thoughtful and articulate approach to how Christians "ought to" view their relationship with the land and how agriculture and farming should change to reflect this, have been schooled in an academic and theological way of framing thoughts. What do farmers who see themselves as farmers, but also husbands, wives, fathers, mothers, Christians, and Pākehā, think about their relationship to the land? How do these New Zealand farmers conceptualize the relationship between their faith and the land on which they farm? It is important to understand the thoughts of the Christian Agrarian movement, for what this brings is a theological perspective to faith and agriculture. However, these thoughts do not account for the everyday farmer who also sees themselves as Christian.

\section{A New Zealand Farmer Understanding}

For many farmers, the concept of "leaving the land better than it was before" is the baseline answer for what it means to treat the land sustainably. In Chapter One I spoke about the contestation that resides within the word "better." In this chapter, I will delve deeper into the farmer's understanding of the balance to how things function on their land in relation to their Christian faith: the idea of "bettering" the land through a practical and "grounded" spirituality. I will do this by focusing on three of the farming couples I interviewed that reflected and refracted the agrarian ecotheology which I discussed above.

\footnotetext{
${ }^{63}$ Wendell Berry, The World- Ending Fire (Penguin Books, 2017), 53.
} 
While these farmers spoke about their land in a variety of ways, the following couples expressed to me a belief that their land was a place God was present. There was a deeply grounded spirituality with which these farmers interacted towards the land, and the practicality inherent to their occupation was apparent when describing their faith. Christianity was expressed through this groundedness, creating what I call a "lived theology," meaning that these farmers have structured their lives in a layering of Christian responsibility and farming responsibility. Rather than speaking about their relationship to the land according to a scholarly theological discourse, these farmers expressed to me their view and treatment of the land they lived and worked on in simple and practical terms, thus approaching their thoughts in the same way they appear to approach their farming: with a grounded, unpretentious, and unassuming attitude. ${ }^{64}$ As I explained in Chapter One, farmers did not articulate a clear systematic theology of sustainability. Rather, it was ambiguous, hesitant, and messy. Similar was their relationship with land and place.

I begin with Betty, whose isolation, community, and traditional faith are deeply rooted in the land her and her family reside upon. Her case study provides insight into a pre-evangelical view of faith that is woven into the everyday fabric of farming life. I then introduce Ash and Caroline, examining how one's land can be more than just a part of the farming business, becoming a vital part of their Christian vocation. Finally, I end with Mitchell and Rhoda, a couple whose sole focus on testimony expresses a vast separation between farm and faith, the land being a black-and-white means to further the farming business and the Christian faith. I use Ash and Caroline's case study followed by Mitchell and Rhoda's to express the juxtaposition between a couple whose spiritual relationship with the land creates a positive view of sustainability and a couple whose spiritual relationship with the land creates a negative view of sustainability. These three case studies create an opening to understand some of the ways different forms of Christianity have influenced the worldview and practices of farmers in New Zealand.

${ }^{64}$ For the word "simple," I use the second definition found in the Oxford English Dictionary: "characterized by humility; unpretentious, humble, modest, unassuming." While often used pejoratively, in the following interview regarding Ash and Caroline, the word is repurposed as an affirmation of a certain level of uncomplicatedness, which has its own aesthetic and ethical dimensions that I will be explaining in this section. For definition, see Oxford English Dictionary, 2nd ed., s.v. "Simple." 


\section{A Tangible Intimacy with the Land}

The majority of farmers I met with practiced forms of evangelical Christianity that influenced their highly personal and spiritual understanding of God and the world around them. However, Betty and her family were one of the few participants whose Christianity reflected a much larger historical pattern of rural New Zealand religion. Woven into the everyday fabric of farm life, Betty's faith seemed less articulate but still vital to her identity. I believe it is important to include Betty in the analysis of Christian farmers and their relation to land and place, for it provides insight into a more traditionalist Christianity. On the wild west coast of Golden Bay, I followed Betty's directions down a paved road until it turned into gravel, driving around a large hidden lake before finally seeing the red shearing barn Joyce had told me about, her house located at the top of a very steep hill. I was met by husband Nick, a quiet man who said hello and then immediately sat down in his chair to watch the news after his long day of working on the 3,000 acre sheep/beef farm. Betty, however, said a loud hello from the kitchen and started talking to me while moving quickly around the house.

We ate dinner together, Betty mentioning that I could go ahead and eat, as they did not pray before the meal. This was the first evidence of the family's relationship with Christianity, an understanding of faith that was less about ritual and practice and more an ingrained part of their identity as humans. Following dinner, wood was added to the roaring fire and the interview began. Nick said he would not participate in the interview, as he was not the best to talk to, so Betty, their nineteen year old daughter Kathy, and I discussed my questions while Nick sat in his chair and continued to watch the news.

Betty began by giving background to their specific place. Following the death of Nick's father, the couple bought the farm from the family trust in 1997. When I asked her what their Christian background was, Betty said,

I was brought up in a Christian home, but [Nick] wasn't. He had a bad illness when he was thirteen and he nearly died .... He always felt that there was a reason because not many people just spontaneously recover from autoimmune disease. I always said that I wouldn't marry someone who wasn't a Christian. He isn't a church go-er, but that doesn't mean that he isn't [a Christian]. He is [just] a self-proclaimed one. 
While Kathy is a Christian, their son Ned has not made a decision on what he believes. When Betty looked at her daughter and asked her to tell me why she was a Christian, Kathy shyly described how she realized that "God doesn't have grandkids," meaning a person cannot rely on someone else's faith, they must have one of their own. The family's Christian background seemed to fit with what I was witnessing as the dynamic of the family. While Nick was the head of the farm, Betty was the social and spiritual head of the family. Religion thus fell along a gendered division of labor. Taking note from their parents, Ned did not care to think about faith, while Kathy did. It was fascinating that Betty commented on her husband as being a selfproclaimed Christian, for it seemed to be her way of justifying Nick's Christianity to her own, as well as giving explanation to how her husband operated and thought about life.

According to Betty, what Christianity most influenced was the way in which her and Nick treated people. Nick, while not overly vocal about his faith, was fair towards all of his workers, a characteristic that she attributed to Christianity. This, thought Betty, was a reflection of his Christian philosophy. He was also very kind when mistakes were made, which Betty saw as a reflection of the grace that he brought to his work. Based on these initial thoughts, it was clear that Betty saw part of being a Christian who owns a farm as remembering that identity is in faith and not in business success. This creates a "grace" not only towards yourself, but also towards the land, animals, and people around you. Betty explained to me that when things went bad, their belief in God helped keep them sustained. They knew "that it wasn't a disaster," believing that God would take care of everything, even if various pressures caused stresses to the couple and to the farm:

And when we are making decisions we don't sorta sit down at the table and pray together, I often have wondered if we should do that more as a good witness to the kids, but we tend to talk about it, [Nick] and I. Sometimes we pray about things, but it is often later. I don't think it needs to come [right away] ... it is something that you do and you don't have to particularly do it right then ... It is a values thing, what is important. Which is your Christian values obviously. And I think you always have the ability to put things behind because things don't always go right on the farm, but you don't beat yourself up when things don't. There is a sort of reassurance that is probably a part of your philosophy, your values, your faith. You are not measured by your [success of] another good year or another good payout or lambing percentage. 
Betty's comments on the couple's approach to prayer was that, while it was important, it did not require regular practice. This did not mean that her faith was insignificant to her, as it evidently was. Rather, the way in which Betty understood Christianity was in a tangible, unemotionallyhyped way. Through her words, Betty expressed to me the notion that faith was important, especially when aspects such as weather were uncontrollable, but it was not something to stress out about. Faith was a relief from stress. It was a way to feel less isolated and overwhelmed, a way to sustain them on the farm. Betty's explanation displayed a belief in Christianity as an opportunity to take negative events less seriously, as ultimately the farm was not under their complete control.

Betty mentioned how farming can be a tough job and it is healthy to have activities that occur off the land. There is a balance between working and not working, and farmers must figure out how to have time off. Understanding that the farm is not always the top priority is a necessary and healthy decision for farmers and their families. While Nick continues to work on Sundays, attending church is a way Betty and her daughter can get off their farm and into the community. Being a part of something else, especially when living isolated, is vitally important to Betty and the health of herself, her family, and her farm. Church, it seemed to me, was a social institution, something important to her personal life as well as her position as a leader in the community. I had heard about Betty from many of the other farmers I met with in Golden Bay, as she was a vital part of the local social fabric. Local marriage and funeral celebrant, involved in many boards and discussion groups, and even having a column in the local paper, Betty was the glue in the community. She was not quiet about her outward Christian identity, but the longer I spoke with her the more I began to notice she was a bit coy about her personal faith beliefs.

I have given background on Betty's Christian faith because it is through this that her relationship to land and place becomes rich with insight. I asked Betty what her definition of sustainability would be, and in her explanation of environmental sustainability, she spoke about soil and stock, meaning land and animals. Through these two words, she expressed an understanding of what the basis for sustainable agriculture should focus on. Betty went on to talk 
about soil fertility, saying that for her and Nick, sustainability meant the health and vitality of the ground:

We do soil tests, [but] we can't over fertilize because our budget wouldn't afford it anyways ... [This] has probably limited what we can do. We have a certain amount that we can spend for fertilizer so we are very careful with what we use and we do soil tests. We don't do any nitrogen at all and any fertilizer that we put on is very carefully looked at.

This explanation of land care raises a question about agricultural philosophy versus pragmatic necessity. Part of caring for the land is understanding what they can and cannot afford. It is a practical view of sustainability, one that focuses on the treatment and maintenance of the land that Betty and Nick live and farm upon. While they must be pragmatic with their practices, this does not mean environmental care is unimportant, and Betty mentioned that "We regress and try to get pastures in good conditions which is part of sustainability, rather than just let it all [go to] slap grazing and farming, so that if we aren't here [someone else] doesn't have to re-develop it." The intimate knowledge Betty had for her land was apparent, as she knew exactly where everything was and what was going on. She also knew that, for her and Nick, it was a smarter decision to simply step back, as opposed to pushing the land harder and resorting to less sustainable practices that could save money and keep business booming. One of the things they have recently been focusing on is reducing stock numbers, becoming less intensive which has been better for both the stock and the land.

One of the most intriguing stories that Betty told me during her description of the family's thoughts on Christianity and sustainability was when Nick had a massive heart attack in 2018 while out on the land rounding up some sheep. Betty explained that this event "probably refocused him. It had been a really dry season leading up to Christmas and he was probably quite worried." This reminded the whole family about the weight of isolated living. Remembering that they are not alone and holding onto a belief that there is Someone greater looking out for the family, the land, and the farm, was crucial for survival:

We were very grateful that Somebody was looking after him because there could've not been cell phone service or he could've not been able to get back on the bike. I wouldn't have been worried about him until much later in the day, so that sort of thing ... and people said at the time, “Oh man weren't you scared? Weren't you panicking?” But I just 
felt really really assured. I had to do what I had to do ... It isn't so much about sustainability but it is about living a little bit isolated. You just have to have confidence in yourself and confidence that you are not alone.

This story expressed Betty's belief that a large part of a farmer living on the land is being able to sustain oneself in an environment that is far away from others. While living closely with the land is difficult and isolating at times, it does have many positive features, which Betty mentioned immediately after her story about Nick:

I think one of the biggest things is that this is a great place to bring up family, that is [sort of why we are here]. And this is a family farm. [Nick] was brought up here. [There was one time that] we were really in financial trouble, we owed $\$ 4$ million at that stage and interest rates were quite difficult. We said if we were sensible people we would just sell up and make $\$ 8$ million ... We felt like we probably weren't very sensible people because we chose to stay ... we felt like this was the place we were meant to be. We could probably walk away and buy another farm for $\$ 4$ million, but you saw this farm, it is a nice farm. Where else would we go ... We don't just stay here because it is [Nick's] family farm, you have to be confident that this is where you are meant to be.

The land was their home and their identity. Betty's story expressed the vital connection between the land and their sense of identity, especially given that it had been a part of the family for generations. Like her pragmatic view of Christianity, her understanding of sustaining both family and farm was highly pragmatic and grounded in the place they lived.

While Betty said that she could not claim to have any extreme spiritual experiences, she did tell me a story about how she was walking along the farm one day during a particularly hard year: "Things weren't going too good one time and I went for a walk early one morning. There was this picture of a cloud and it just looked like sort of a bird with the wings spread out across the farm and I was like, yeah, I will take that. It felt like it was assurance that the farm was covered." She has carried this bird-like cloud image with her for years, as it constantly reminds her of God's faithfulness. This story about a strange spiritual experience was important for a few different reasons. Betty's inclusion of a seemingly random occurrence expressed to me an underlying feeling that she needed to have a spiritual experience if she was to say that she was a true Christian. This furthered my understanding of Betty thinking she did not have a strong enough faith on her own, that other farmers had better language to describe their thoughts on 
Christianity and agricultural sustainability. In a Christian space that increasingly has become evangelical in its spirituality, a traditional and "salt of the earth" Christianity like Betty and Nick convey might seem a bit out of place and out of date. An independent Christian woman who was a leader in her community - acting as a foster parent, a church member, a coordinator of the sheep and beef discussion board, and a local marriage and funeral celebrant - there was a sense of meekness when it came to personal spirituality. However, Betty's inclusion of the bird-cloud story also created a relationship between Betty, the land, and God. She could not fully interpret this event, for it was not a practical or tangible event, but she knew it was meaningful. Seeing a sign from God in the form of a bird swooping down onto the farm spoke of God's provision towards the sustainability of the land and the family.

Living isolated is challenging. However, both Betty and Nick were tied to their land and they were unwilling to let go, even in the face of economic hardships. The image of the birdcloud that Betty spoke about further showcased to me the idea that, while they may be isolated, the family and the farm were not alone. There was something, Someone, greater that was with them. God has sustained them by being present in the midst of their isolation. Betty's description of the land expressed to me that it was a space of bringing people together, as well as serving others. Sustaining the land is not only to keep their farming business sustainable, but also to bring others onto it. According to her, "It is bigger than just our little puddle, which I think is important [to recognize]. So sustainability is bigger than our little place." Sustainability was seen as both family and lifestyle continuity.

This narrative is an important one for my research as it expresses an often overlooked form of current Christianity. Betty and her family saw their faith as important to them, but their expression of this faith was different than many of the farmers I met with. She expressed a belief that God was a vital part of the continuation of farm and family, but it was a less articulate and emotionally-hyped understanding. God was woven into the very fabric of the land, an integral aspect of why and how the family was able to sustain themselves and their agricultural practices. This was seen in Betty's story of the bird cloud. However, thought that narrative, it is also seen that she is not sure what to make of the experience, only that it happened and it brought her peace and a sense of God's presence. 


\section{Communion with the Land}

While Betty expresses an intimacy with land and place that is difficult to describe, there were some couples who had terms for the way in which they interacted spiritually with their farm land. This does not mean that one couple was more spiritual than the other. Rather, it showcased a difference in Christian denomination, generation, background, and practice. One such couple that had terminology for their intertwining of faith and farming was Ash and Caroline, who saw the farm and the land it was a part of as vital to their ultimate work for God. Sustainability is solidly rooted in spirituality, and treatment of the environment directly correlates to their belief in Christianity. The way in which they interact with their land is also ritualistic in nature, as the couple both literally and metaphorically partakes in communion with it.

Deep in the King Country, I found myself driving through beautiful rural countryside and onto a long gravel road. I was struck almost speechless by the scenery around me: magnificent rock cliffs rising up on my left while a flowing river ran along the road to my right. Thirty minutes later and I was still driving. I was enamored by the land around me, while also really hoping that I was going the right way and would not end up hopelessly lost, stranded alone in the middle of nowhere with no cell service. The road finally opened up into incredible farmland and a large wooden range station sign.

Met at the door by Ash and Caroline, I was warmly welcomed inside for lunch while we talked. Ash explained that he was a generational farmer from the Waikato and that Caroline was from a medical background in Northland. While Ash had been raised in Sunday school followed by attending an Anglican boys school, he became involved with alcohol and gangs, not considering himself a Christian until he was thirty-six. Caroline was brought up in a nonChristian home, converting to Christianity while living in Saudi Arabia when she was twentytwo.

Ash and Caroline were no strangers to discussing the topic of sustainability. Caroline noted that it was the classic idea of leaving things in a productive state for future generations. Ash then spoke about how to be sustainable was to not "rape the land," saying: 
We don't want to take too much. We aren't into making the biggest profits or putting the most fertilizer or the most inputs on. An example would be this [past] summer [which] has been the driest it has ever been. [This has hurt] and exhausted the country. And I am just thinking that, with my sense of the country, [the land] needs a rest. So we will restock, we won't replace stock for twelve months, and we will gradually restock over the next six months.

To Ash, part of sustainability was ecological flourishing. The language of "rape" was continually repeated in a number of interviews I conducted, as well as being a large part of the Christian Agrarian literature I read previous to my fieldwork. The word itself is visceral and violent, and implies a metaphor for immoral or repugnant use and violation of the land. This sexual metaphor suggests that a proper relationship to the land should be mutual, consensual, kind, and tenderly intimate, relating to the language Kramer uses in the quote given at the beginning of this chapter. There must be a relationship between the farmer and the farm, the person and the land. Not only that, but Ash's explanation of his land portrayed a required high quality of relationship. Part of understanding the land was knowing when rest was needed. As a result, Ash and Caroline were also firm believers in giving the land rest, letting it lay fallow, a term Ash specifically used, for certain periods of time.65 Ash commented on this idea by saying, "When you look at it, we are such temporary beings ... There is not much more being made. It doesn't matter what you do with the land it will still be there, in better condition or in worse condition but it is still there. And we will be long gone."

Understanding what kind of land you are living on, according to Ash, was one of the things that farmers had failed at in recent years:

I think one of the main things that farmers have really stuffed up is trying to change the land to suit the stock instead of farming the stock to suit the land, and I think that is critical. Every block of land has an optimal production level, especially with this sort of country ... Why are they trying to push farmers to try and get more per hectare? This stresses out the land and it stresses out the farmers. Why should we always be trying to

\footnotetext{
65 The idea of fallow farming is a biblical principle. Berry describes the history of this term saying, "In token of His landlordship, God required a sabbath for the land, which was to be left fallow every seventh year ... But beyond their agricultural and social intent, these sabbaths ritualize an observance of the limits of 'my power and the might of mine hand' - the limits of human control. Looking at their fallow fields, the people are to be reminded that the land is theirs only by gift; it exists in its own right, and does not begin or end with any human purpose." See Wendell Berry, The Art of the Commonplace, (Berkeley, CA: Counterpoint, 2002), 296.
} 
increase what we get off of here and push ourselves ... Perhaps we could legitimately, if we put aside all of our values, get more production out of the land. But then what does God want us to do? It is about combining the lifestyle and everything else.

This quote expressed to me a belief that God is actively involved in how the couple treats their land. With 4,000 out of the 6,000 acres of the farm containing wild bush, it has become a valuable space for people to tramp, fish, heal, and be close to nature and to each other. Everything occurring on their property was understood to be a ministry for God, with the spirituality of the land aiding to the positive environment that it brought to all the people who came to visit. Both Ash and Caroline knew their land and the way in which it worked. The comments made showcased care taken towards the couple's land and its health and well-being. It also expressed a deep thoughtfulness towards the couple's actions and a desire to create language, both spiritual and agricultural, for these actions.

Ash and Caroline told me a story about how they had traveled around their farm carving the word "Shalom," a Hebrew salutation meaning wholeness, peace, and well-being, into various fence posts and trees. They then spent time praying over the land before partaking in the Christian sacrament of communion, burying the leftover bread and wine as a way to physically connect the ritual to the land. Caroline explained their actions:

I heard this thing about a farmer who was really not doing well. They went and spread salt at each of his gateways and they prayed throughout his farm, and it made a difference to what was happening on the farm. Here ... we have gone and prayed in a spot and we have taken communion and we have buried the rest of the communion there ... This isn't our farm it is God's. We are just stewards. He owns the cattle on a thousand hills, not us. We are blessed to be able to take care of it for Him and [for] future generations of people that He will bring here.

This quote directly expresses sustainability as a response to God's gift of the farm. I smiled as I looked at Ash, who was rolling his eyes at the story. I could tell he completely believed in their actions, but, as he explained after the story was told, "We are weirdos. I know it sounds really really wacky." This discourse of disassociation, calling Caroline and himself "weirdos," located themselves self-consciously against a perceived dominate cultural grain. It showed to me that they were not oblivious to how strange their ritual practices might sound to an outsider, and they 
acknowledged it as such. However, they did not step back or try to hide this aspect of their Christianity. It was how they related to the land, this "wacky" practice being a vital part of their lives. Ash and Caroline deployed "weird" ritual practices to ground their spirituality to their farming. Unlike Betty, who self-consciously described her experience with "the bird cloud" as a spiritual sign from God, Ash and Caroline were more comfortable with strange and unexplainable Christian experiences.

This ritual act of communion, followed by a burying of excess bread and wine in the land of their farm, creates a literal meaning within the idea of "grounded spirituality." Ash and Caroline's Christianity physically became one with their farm land. The act of writing Shalom on fence posts around the farm had similar effects, taking physical action to join God to the farm and to the land. This ritual practice of grounding themselves was fascinating, and the narrative around Ash expressing that it was a "weird" practice further expressed his understanding of ritual strangeness.

When I asked the couple to describe how they saw their personal Christian faith as intertwining with their farming lives, Ash talked about their personal financial position in relation to their faith. I found his understanding of debt strangely positive, for many of the farmers I spoke with seemed to be weighed down with the burden of their constantly growing debt:

We have debt but we aren't bankrupt and God keeps blessing us. I suppose you can't out-give God. I am not into that theology of "name it and claim it," but we are into the theology of "blessed to be a blessing" - the Abrahamic covenant. I think that is the key. When you look at the key scriptures of how we are involved in the world, it is the Abrahamic covenant, the great commission, and Micah 6:8 ... I think that the more complicated your faith becomes the harder it is to accept the simple things in life. ${ }^{66}$

\footnotetext{
${ }^{66}$ The "name it and claim it" theology that Ash mentions comes from the Pentecostal Prosperity Gospel, which became popular in the 1980s. This gospel centers around the belief that the Christian God desires followers to be socio-economically prosperous. Prosperity can be attained through the giving of offerings, spoken confession, and the belief that God will provide. See Matthew Sharpe "Name It and Claim it," in Handbook of Research on Development and Religion, ed. Matthew Clarke (Edward Elgar Publishing Ltd, 2013), 164.
} 
Ash's view of farming, whether it be the financial aspects of it or the way in which he treats the land, is steeped in the idea of the simple. This "simple theology" seemed an attempt to keep things relatively uncomplicated. Why make things more than they are, dressing them up with fancy words and big theories, when issues can be fixed with the basics. Simplicity is the way in which they live and relate to the world around them, letting things come and go, letting nature take its course. Ash told me that his spiritual motto (to which Caroline rolled her eyes) was "Shit happens." This motto seemed to be to be an acceptance that negative things will happen, but that there should not be much anxiety or worry placed upon these negative occurrences. It was a peaceable and good-natured way for Ash to view his Christianity, practically understanding that there is no reason for worry in a world that will contain both good and bad. Even though they were in debt, all was well. In fact, being able to focus on something beyond the farm was good for their overall health. Caroline commented on this, saying,

I think part of the thing is that we have had this passion to do things overseas and so maybe if we hadn't had that and maybe if we weren't Christians and following God [we would've] been pushing it to the limit here. I think that being a Christian farmer [means understanding] that there is more [to life] than just farming. But I do have to say to [Ash] every now and then, "Who's kingdom are you building."

The choice Caroline uses to say "following God," rather than believing in God, describes a discipleship mode of engaging with Christianity. To me, she was expressing an understanding of sustainability as a critique on capitalistic greed, acting with calmness and restraint in the face of capitalist striving. It is practical and active, rather than a passive belief. This is furthered by Caroline reminding Ash of what the purpose of their farming is - it is for God and the building of His kingdom. Christianity is therefore an active choice that affects the decisions that are carried out. Whether it be through the ritual of communion on the land, helping with overseas missions, or performing daily farm chores, Christianity actively engages with and grounds their actions.

Ash then spoke about the holistic respect and appreciation you must have of everything and everyone around you. He saw Christianity as impacting how they farmed, helping them to respect the land, the animals, and the people. It was all about balance and the realization that the farming aspect is only one section of a greater narrative. As a balance, farming is about the ways 
in which each aspect is navigated in relation to one another. Christianity, therefore, is not so much a solution to problems faced as it is a requirement to ensure that financial goals will never be considered the sole focus. Caroline explained this idea by saying:

Maybe 20 years ago, if you were a Christian and you were very very focused on your business, some people thought that you [were] a second-class Christian because you weren't in ministry, etc. For us, we have always seen this place as our ministry for God, our work for God. We are still involved in lots of other things, but we very much acknowledge that if you are in business and you have a full-time job doing something in the so-called "secular world," that this is your ministry and that is what God has called you to. This farm, and farming this farm, is part of what God has called us to ... We are just a really small part of it, but we [do] need to facilitate it.

Caroline's words expressed the idea that if this land was to be their Christian vocation, they must treat it well, not only for the sake of their business, but also for the God who has entrusted the place to their care. Through their interview, the couple conveyed a shared relationship with the land, one that required both parties to work together for the common sustainability of everyone and everything involved. It was a belief of working with the land, rather than on it. While their thoughts expressed this belief, the taking of communion on the land and then burying it portrayed a grounded action between the land, the couple, and God.

\section{Claiming the Land for Christ}

Ash and Caroline were not the only couple to physically express their faith on the land. This grounded spiritual action between farmer and farm creates a dialogue and a discussion around what land and place represent - does this action represent the ecological and environmental, the plants and animals that live in it; or does it represent the community, the human beings that live there? This was a question brought up through my spur of the moment interview with Mitchell and Rhoda which was scheduled after one of my farming contacts called to tell me that he was not able to meet due to a medical emergency, but that he knew of some Christian farmers who might like to talk with me. Upon flying into Hamilton Airport, I got a call

from Mitchell saying that he had been given my phone number and could meet around lunchtime if I did not mind traveling to South Waikato. 
Driving up a steep gravel driveway, I knew I was in the right place the moment I saw a giant wooden cross erected upon the grassy hill opposite the house. The couple welcomed me inside and we sat down at their dining room table that was covered with piles of bills and important documents pertaining to the business. Before starting, Rhoda warned me that Mitchell could get off track quite easily, but that she would make sure to focus him. After asking my first question, I was unable to bring up any of my proceeding questions due to the fact that Mitchell got swept up in the testimonial narrative that has been his life as both Christian and farmer. The conversation went on for just about two hours, with Mitchell continuing to speak until I had to stop him for fear that if I stayed any longer I would have to spend the night. Rhoda continually aided in focusing him during long tangents, as well as often clarifying what Mitchell was saying.

Christianity has always been a large part of Michell's life, with his grandfather moving to South Waikato from Switzerland after an "obvious sign from God" told him that he should move here with his family. Mitchell and Rhoda bought the current farm in 1999, originally milking two hundred cows on seventy-four hectares of land, before being offered an additional thirty-two hectares. While Mitchell grew up Presbyterian and Rhoda grew up Catholic, the couple decided to join a Baptist church for their children as it had the best youth group. "If your kids are in the right circles, it makes a huge difference." Two of their four kids have come back as adults to share in the work on the farm.

After a brief introduction to the farm, Mitchell began talking about what it was like being a farmer living and working in New Zealand. While he felt lucky, the country was not, in his opinion, immune to issues caused by the environmental critique of farming:

Farming [had] been good for us, but [then] environmental stances started changing. There were lots of rules and regulations. For a farming couple that was not used to any rules and regulations this was a change. [This] would've happened in the late $80 \mathrm{~s}$ or early $90 \mathrm{~s}$, but in the start of 2000 it really changed. Fonterra was formed around [that time] and came out with the slogan "the image of clean and green" and not long after that the words "dirty dairying" came up. The image we had had of clean white milk and money were starting to change and our lifestyle started to change too.

This was a touchy subject for the couple, who saw themselves as victims of a blackened image that was given to dairy based upon a few bad farmers. Through Mitchell's word choice of "clean 
white milk and money," he directly correlated their dairy practices with monetary success. It was as if being environmentally sustainable related to being economically sustainable, but this was not the case according to Mitchell. A major shift began for the couple, changing how they looked at and treated their family farming business. The new rules and regulations caused a somewhat forced entry into a focus on environmental sustainability. While they did not say so directly, the way in which they spoke about the popularity around sustainable agriculture and how they had to change their practices portrayed frustration and feelings of being misunderstood. Farming used to be good to them, until backlash began and they had to change things to be more mindful of rules and regulations. Sustainability seemed to be more of a forced chore than a desired choice.

Another thing that changed their farming practices was a short-term missions trip to Australia that Rhoda went on with a group of singers in 2000. Mitchell explained how his wife had gone away a "quiet, meek mouse" and came back "really bouncing from wall to wall humming." According to Mitchell, Rhoda had seen God providing for others, "and for a while there I was wondering if I would ever be able to tie her down." This trip changed the way the family farmed, "because before then our focus had been solely around money and family, but there was more to be had." The trip to Australia was a profound spiritual experience, directly for Rhoda and indirectly for the rest of the family and the farm. While not related to environmental themes, the experience itself had a profound effect on Mitchell and Rhoda's farming practices. It was a result of this trip and the changes in Rhoda that the family realized how much more they should focus on their faith. "There was more to be had" than just family and farm dynamics. There was something greater to work towards. This being said, the trip changed the couple's farming focus, not towards a desire for sustainable agriculture, but more towards a desire for sustainable community.

After this experience, everything seemed to go well for the family, partially due to the fact that, according to Mitchell, "we didn't have the environmental standards that we had to comply to or spend money on, so they were good years." Strange phrasing for an issue currently so important for agriculture, this explanation expressed to me an idea of sustainability as regulatory regime. Sustainability relating to the environment was something impinging upon their freedom and impacting their profits. The rules and regulations, as explained above, also 
point to Mitchell and Rhoda seeing environmental standards placed upon farmers as an annoyance to their otherwise peaceful and successful farming business. These changes to their farming practices, whether a change in focus due to a short term mission trip or new rules and regulations being thrust upon the family, were explained in a way that gave me insight into what was important to the couple. While Ash and Caroline embraced an active combination of spirituality and sustainability and Betty expressed a tangible pragmatism regarding her relationship between spirituality and sustainability, Mitchell and Rhoda spoke in a way that suggested a disjuncture between sustainability as an externally-imposed regulation that had little religious resonance. The two appeared to have little to do with each other in their narratives of explanations. Sustainability got in the way of what was most important - the business, the family, the community, and Christ.

Yet, over the course of our interview, Mitchell and Rhoda indicated a theology of the land as a space for miracles. God's provision was evident, and many spiritually-charged occurrences have taken place on the land around them. Mitchell explained:

God gave one of the men in our church a Word that they were to claim the town for Him. ${ }^{67}$ We had a men's meeting and we prayed about it and a prophetic gentleman got up and said he believed we needed to go to the gateways of this town and pray for it. There are only a few roads that go into town, so the next men's group ... one guy came along with stakes and we all took them out into the various roadways at $8 \mathrm{pm}$. We drove the stakes in and claimed the town for Christ ... Two weeks later we had a lady come up to our house and said her car was broken down. She was a big woman all dressed in flowing black. I said that I would go down and help her. I got halfway across the cattle stop, which is the boundary, and God just put "witch" in my head. I thought, no that can't be. But when she got out of the car there were three snapping dogs in there and they were just hissing and growling ... I went in beside [the car] and popped the bonnet and held [the jumper cables]. For some reason I [just told her to try and start her car], I didn't even touch it with my jumper leads, and it started straight away. I went around to her and [asked if I could pray for her]. I reached over to pray for her and ... she was gone like a shot.

${ }^{67}$ The phrase "claim the town for Him" is used by Mitchell to express his understanding that God wanted the men of the church to officially declare the town as owned and controlled by God. 
Mitchell explained that many strange events occurred in the town after they claimed it for Christ. Once the stakes were driven into the land, Mitchell discerned a real change not only in the men who were a part of the group but also in the town in general. According to Mitchell, "We didn't realize how significant that was until [we] saw all the rubbish that happened the next two or three months. The devil tried to come in and upset things. All of a sudden people would start leaving town." These were clearly spiritually-charged occurrences, but they did not appear to be connected in any meaningful way to my interest in understanding sustainability. However, if one understands sustainability as keeping the land safe for the Christian community, rather than taking care of the environmental aspects of the land, Mitchell's relationship with the land begins to make greater sense. Sustainability as environmental protection is here seen as a threat to the Christian faith and community. His lack of conversation regarding sustainable agriculture relating to the land and the animals showed that he saw an environmental focus as nothing more than something they had to do in order to continue with the business. It was the spiritual aspects of life that needed to be sustained. It was the land in relation to "claiming it for Christ" that needed to be sustained. Sustainability, therefore, was a response to God's gift of the farm.

Many other stories were told by Mitchell and Rhoda about how God had worked in the community and on the farm. There was no mention of the environment, other than in relation to what had occurred on the land that related to their family and community. Every story told seemed to be simultaneously miraculous and deeply practical, using the structure of "And days later, it just __ !" This combination of miraculous and practical was an intriguing and notable combination, one that paralleled the couple themselves. Practical in the way they conducted their farming business, they were frustrated by the way rules and regulations caused them to change their agricultural practices when things seemed to be working smoothly. Miraculous in the way they saw their Christianity, they understood events happening over and over again as justifying their faith and strengthening their testimony.

Expressing Christianity's impact on the farm, Mitchell told a story about when the majority of his animals became sick: "We had an attack on the farm of animals getting sick and dying. One night at 10pm after men's group, [all the men] ended up down the road. They prayed for the farm and for [the sickness] to stop and for God's blessing and for peace for our family. 
Two days later it stopped just like that." To be a Christian meant that you brought your faith into all aspects of your life, in how you interacted with and treated both your farm and your neighbors. His choice of words in these stories - the "attack" that occurred with the farm animals, the description of a "witch" in "flowing black," the fact that "the devil tried to come in and upset things" - pointed to a discourse of spiritual warfare. This language, as well as the hostility of magical witches and a distaste for anyone who was not a Christian, was a language stemming from the action of driving stakes into the ground. A grounded physical action taken upon the land that created a rooted spiritual effect.

In an interview that consisted primarily of Christian testimony, the topic took a turn towards environmental issues at the end of our time together, with David saying that "The end of the world is going to come in a different way than we think. It will come in the form of not being able to drink water because it isn't pure enough or not having clean enough meat. It will be environmental standards. The world is changing..." This was the only reference directly made to the idea of sustainable farming practices. What I found fascinating about this being their only real reference to sustainable agriculture was that environmental standards directly correlated to the end of the world. It was not a conversation about what to do about all these negative things, or how to change practices so that the health of the world might improve. The changing of the world, the lack of clean water, the unsafe meat - these were all examples of the downward movement of the world.

When Mitchell finally stopped talking, I asked a direct question as to whether or not they saw their faith informing their view of sustainable farming practices. Mitchell answered that, "as a young man I could get bad tempered and this was at the time of me worrying too. I did not have patience for animals. I wouldn't hurt them but..." This was an intriguing comment, reducing environmental sustainability down to animal welfare. At this moment, Rhoda interjected, almost as if she was protecting and justifying her husband's comments regarding an impatience for animals:

Farming is a black and white business. If something doesn't perform, you cull it. And unfortunately town versus country doesn't understand that. So all the things that they talk about - "Oh that poor chicken is going to die because you want to eat it" - well, it is very 
hard to talk to a person who feels like that [regarding] anything you do on the farm. [If] a cow does not perform or is sick, we have to send it to the works. You don't let it suffer. At a certain degree you can fix things, but it is about income too. I would say that in the last fifteen years my husband [has become] softer with the approach of an animal and he will work with them more so than he has in the past and with more compassion. Definitely [Christianity] has had an impact, but at the end of the day when it comes to paying the bills, you do what you have to do. So you combine the two - faith and farming.

This quotation expressed the pragmatic side of faith. It also expressed to me a determined argument against sustainability, as environmentally-friendly farming practices were unhelpful to one's business. This was an explanation of being pragmatic in one's faith and farming relationship that I believe many of my other farmer informants, including Ash, Caroline, and Betty, would find weak and shallow. It was an excuse, rather than a justification, for why they did not engage in more sustainable agricultural practices. Environmental sustainability correlated to the "town," synonymous with "rules and regulations" that created issues with their successful farming business. Sustainability was placed upon farmers by those who did not understand that farming was "black and white."

We ended our discussion and I asked if they could point out the boundaries of their land. The house was located on a hill in the very middle of the property, green pasture all around them, with the town in the distance. Looking out over the hill, the cross shone as a large testament to Who the land belongs to. It had been claimed for Jesus. Mitchell and Rhoda worked and maintained the farm, but it was owned by God. This was their ultimate testimony, a physical reminder for both their Christian friends and "unbelievers" just passing by. How much did land actually enter into the narrative of Mitchell and Rhoda? One could say that it did not enter into it at all, that the cross was not so much about a connection to the land as it was an attempt at public testimony. However, I have chosen to include this interview in the chapter about the land because of this unclear and murky portrayal of sustainability. Their lack of conversation regarding environmental treatment expresses a relationship with the land and how they see it in connection to their faith. I entered into their space asking them questions about how their faith influenced and impacted their farming practices and their sustainability, and instead of speaking about the ecology and the environment, Mitchell and Rhoda gave me their testimony. They took a 
conversation about sustainable agricultural practices and made it all about their particular Christianity. This was an uncommon approach to my interviews, as the majority of the farmers I met with seemed more comfortable talking about their farming than their personal spiritual journey.

While they did not specifically touch on the physical land they farmed, as well as hardly speaking about their sustainable agricultural practices, it was clear to me that what happened on their land held much weight to both Mitchell and Rhoda. However, this was not due to an understanding of sustainability or environmental practices, but rather it was due to a their strong cosmology of spiritual warfare. What took place on their land was spiritually important rather than relating to the environment. The land was rendered as "community" rather than ecology. The land was a space to actively and publicly express their Christian faith to those around them, and the way they spoke of the farm itself, as well the land and the animals that were a part of the farm, were nothing more than a part of the business. Ecology and animal welfare were outsider concerns, and often a burden towards their overall testimonial goals. The stories they told were very focused on their faith and how it related to the place they lived on and with. It was through the testimony they shared that they showcased their anxiety and responsibility towards their land and the large wooden cross on the farm served as a representation that their land was claimed for Jesus and was therefore a spiritual space.

\section{The Various Levels of a Grounded Faith}

It can be seen through these three case studies that there is a connection between a farmer's faith and their understanding of the land that they are on. However, how can all of these farmers with different understandings of the land and Christianity, all contain the "lived theology" that I mention at the beginning of the chapter? While it may not directly correlate to a practice of sustainable agriculture, a belief in the materialization of the divine on their farms gave the farmers a particular understanding of their farmland. At the base level, it can be said that they see the sustainability of their land as a testament to their personal continuation sustaining the land means that they have successfully sustained their family's livelihood. On a deeper level, however, sustaining the land, making sure that it is healthy and will be able to 
continue long after they themselves are gone, is an action that insures a continuation of God's presence in a world that is becoming increasingly difficult for them to relate to and understand.

There is pride in the land that the farmers live on, work, and own. This pride comes from a belief that their work as farmers is necessary and good. However, it also comes from a belief that God has sustained the work of their hands when they were not mentally or physically able to. This creates a sense that their work is divinely necessary and good. Based on this, it is my understanding that this close connection between farmer, faith, and livelihood is a large reason as to why they feel personally attacked in varying degrees by environmental issues, laws, and regulations. There is a perpetually growing fear for farmers of the unknown, both the unknown in nature and the unknown in the socio-political climate. This fear creates a desire and a deep need to have something to hold onto that is greater than who they are. By relying on their faith and believing that God resides physically on their land, there is assurance that what they are doing is important and not simply worthless toil. The three farming couples I met with express the tensions that come with being a farmer, showcasing the way they understand the sustainability and treatment of their land in relation to how they understand themselves to be as Christians.

My central argument within this chapter is that the way in which the Christian farmer relates to their land can often be filled with spiritual experiences relating to land and place. Whether it is "claiming the land for Christ" through erecting a large wooden cross on the highest point of the farm, conducting the ritual of communion on the farm and then burying it, or seeing a large bird-like cloud as an image of promise that the farm is in God's more than capable hands, this "lived theology" speaks towards a fear that is inherent to living rurally isolated in a country becoming increasingly urban and increasingly secular. For these farmers, it is faith that sustains them, explaining why bad things might happen but why they also do not need to lose hope given that it is controlled by a greater presence. The sustainability of the land is deeply grounded in the spirituality of their lives, if for no other reason than equating the continuation of their farm with the continuation of themselves and their faith. It seems that there is a love and appreciation for the land not because of the farm but because of the other aspects that the land brings community, hope, the bush, and God. 
While the farmers that I spoke with were not outwardly "Christian Agrarians" in their farming approaches, they were nevertheless spiritually connected to the land they resided on, albeit in different ways. They did not attribute their care for the land and their understanding of the space they live in to the theologies of of Kramer or Berry, but they do take time to contemplate their land and they do connect it to their Christianity. This idea of connection and care clearly means different things to different people, depending on where their priorities and beliefs lay. But as seen in each of the interviews I discussed in this chapter, connection and responsibility are both present. The tension found in searching for an all-encompassing definition of sustainability directly correlates to the tension found in understanding the relationship farmers have with their land and how this can relate to their sustainable agricultural practices. 


\section{Conclusion}

Through the examination of tensions of sustainability, community, and land and place, the interviews explained within this thesis give understanding to how farmers see faith and sustainability in the context of New Zealand. Land and community, interwoven and flowing together into a definition of sustainability that is filled with tension. It is my hope that through the telling of these stories, and through the opening up of rural New Zealand Christianity and farming, that something of the diversity of Christian farmers has become apparent. I entered into my fieldwork with the idea that farmers would see their faith as deeply connected with, and consequently for, the engagement with the animals and land that were a part of their farm. Or, perhaps in opposition, that the farmers would see their faith and their farming practices as completely separate. However, what I found instead was a deeply rooted, rich, and complicated system of rural Christianity that influenced and effected not only the way that participants saw their farming, but also how they saw themselves, their communities, and the rest of the world.

I have employed the use of detailed case study analysis to explain the various definitions of sustainability, the importance of community to sustainable agriculture, and the complexity of the spiritual relationships between farmer and farm. Through the interviews of Carl and McKenzie and Jake and Irene, I showcase how faith and farming intertwine through the practicality of sustainability, the husband and wife team dynamics, and the importance of rest and celebration on the farm. Through the interviews of Fletcher and Joanie, Edward and Ruthie, and Martin, Katherine, and their son Paul, I express the varied understandings of community in relation to the farmer's Christianity and treatment of the farm. Finally, through the interviews of Betty, Ash and Caroline, and Mitchell and Rhoda, I give detail to three understandings of land and place in relation to spirituality, this then informing how the farmers understand the sustainability of their farms.

What I found in my research is that farmers in New Zealand know they have to be sustainable in their agricultural practices. They are also part of Christian communities. These two aspects of their lives do in fact connect, but the problem is, no one is asking farmers how they connect. This thesis acts as an invitation to further research into rural church communities, the rural understanding of sustainability, and a farmer's relationship to their land and animals. There 
is both an interconnectedness and a disjunction between farmers and their land and animals, and there are many tensions within the definition of sustainability. To answer the question of what we should do with these tensions, conversations must be opened up regarding religion, sustainability, and the urban/rural divide. There is only so much that I was able to accomplish through my research, and there is much more to be discovered. My research focused on Christian farmers. What about those of other religious beliefs and backgrounds? ${ }^{68}$ My research focused on Pākehā farmers. What about Māori farmers and their relationship to spirituality and sustainability? My research focused on conducting fieldwork only in the Waikato and Nelson/ Golden Bay areas. What about the other regions of New Zealand?

The writings of Christian Agrarians are helpful for articulating a connection to farming and faith in North America. There now must be articulation given to the connection between farming and faith in New Zealand. John Ikerd states that sustainable agriculture is "a living system; it is individualistic, site-specific, and dynamic. Thus sustainability must be assessed within a specific context of people, place and time. Sustainable agriculture is diverse, and thus cannot be captured in a few examples or studies." 69 If sustainable agriculture is site specific, a greater focus must be given to the local spaces around us. Ikerd then says that, "If farming is to survive as an occupation, we must rediscover agriculture." 70 We must also rediscover the rural space and the life of the farmer in a world that is increasingly urban.

The title of this thesis comes from an interview I conducted in Taumarunui with Jim and Marge on their hill country sheep and beef farm. At the end of our time talking about sustainability, Jim gruffly explained to me how his farming and faith intertwined:

They are two different things but they are actually very tied together. I had pastor one time and he asked me [how I was doing] because my second wife died of cancer while we were here and I went through all that. Some shocking things have gone on in the nearly twenty years that I have been here ... This one time I was thinking about selling [the farm] but then I thought, "Nah, God gave me this farm He will show me when it is

${ }^{68}$ Farmer's Weekly published an article on a Muslim farming family in Southland and how their faith has impacted their farming practices. See Sonita Chandar, "Faith, Family and Farming," https://

farmersweekly.co.nz/section/other-sectors/on-farm-story/faith-family-and-farming (accessed 3 November 2019).

69 John E. Ikerd, Crisis \& Opportunity (University of Nebraska Press, 2018), viii.

${ }^{70}$ Ikerd, Crisis \& Opportunity, 63. 
time to chuck it in." So I got through that lot and carried on. You know, quite often in those times I just think, "Well God put me here, I guess I am supposed to be here." Anyways, so the pastor came up to see me one day after Jane died and he said to me, "Where do you find God?" and I said, "Out the back of my farm, leaning on a fence post somewhere."

The story that he told at the end of the interview showcased his understanding of the farm as divine gift. Where did Jim see God? He saw God out the back of his farm, leaning against a fence post. The land that he lived on directly expressed his faith, and it was on his land, on his farm, that he saw his faith as physically manifesting. The definitions of sustainable agriculture might vary from farmer to farmer, as do the beliefs and practices of their Christianity. However, as seen in the case studies detailed in this thesis, the language of God being a part of the farm was something inherent to the conversation around land, animals, community, farming life, and sustainability.

The farmers I met were real human beings, full of tension and conflicting narratives and beliefs. Their actions and beliefs both correlate and are inconsistent with one another. Whether positive or negative, this is an argument for attending to empirical complexity, rather than abstract "ideals." After two weeks of fieldwork in the Waikato and two weeks of fieldwork in Nelson/Golden Bay, I soon realized how simplistic my research desires had been. This was due to a few things, first and foremost being that the farmers I met with were not two-dimensional black and white characters. Through the process of having to prove myself as trustworthy both as an outsider of their home and of their country, sharing thoughts and cups of tea, I realized that the topic I was researching and the farmers I was meeting with were creating tension with one another. What I found was that rural farmers in New Zealand have very few words given to speak their worldview. With little written research about rural spaces in New Zealand, especially in regards to religious customs and beliefs, I believe that this is a problem that perpetuates the misunderstanding and divide between urban and rural spaces, as well as a missed opportunity to aid in creating more sustainable agricultural practices.

It is my hope that at the end of this thesis a greater understanding of the diversity of Christian farmers has become apparent. Sustainability to the rural farming community is not simply a one dimensional definition. Rather, it is a rich combination of farming knowledge and 
Christianity which impacts how farmers treat the land, the animals, and the communities that they live amongst. Sustainability is a problematic notion, filled with ambiguity, contestation, and diversity, that is not solely focused on the environmental aspects. Therefore, a straight-forward definition of sustainability and how it relates to faith is too simplistic. When relating it to farming, it is an ideology steeped in community engagement and spiritual connections to the land, all of which influence and impact sustainable agricultural practices on New Zealand farms. 


\section{List of Participants}

Colin and Dorothy

Tim and Mary

Ross and Shayney

Robin

Jess

Vaughn

Richard and Leentje

Colin and Julie

Roger and Aynsley

Robin and Lauren

Allen and Steph

Peter

Malcom

Phil and Pam

Tim and Rachel

David and Carla

Paul

Melvin and Caroline

John and Shirley

Roger and Cheri

Chris and Jan

Ernie and Heather

Gray

Jock and Joyce

Wayne 


\section{Bibliography}

Bartlett, Hannah. "Renewing the Lungs of the Land." Flint \& Steel 3 (2016).

Beattie, James, and John Stenhouse. "Empire, Environment and Religion: God and the Natural World in Nineteenth-Century New Zealand.” Environment and History 13, no. 4 (2007): 413-46.

Beef + Lamb NZ. "Beef + Lamb New Zealand's Farmer Councils.” https://beeflambnz.com/ your-levies-at-work/beef-lamb-new-zealand-farmer-councils (accessed 30 January 2020).

—. "Beef trial: 30 versus 60-day winter rotations." https://beeflambnz.com/news-views/ beef-trial-30-versus-60-day-winter-rotations (accessed 30 January 2020).

__. "Business Plan." https://beeflambnz.com/knowledge-hub/PDF/business-plan-template (accessed 20 January 2020).

Berry, Wendell. The Art of the Commonplace: The Agrarian Essays of Wendell Berry.

Berkeley, CA: Counterpoint, 2002.

—. Bringing It to the Table: On Farming and Food. Berkley, CA: Counterpoint, 2009.

—. The World-Ending Fire. Penguin Books, 2017.

Blachard, Kathy D., and Kevin J. O’Brien. An Introduction to Christian

Environmentalism. Waco, Texas: Baylor University Press, 2014.

Brown, Edward R. Our Father's World: Mobilizing the Church to Care for Creation (2nd ed.). Downer's Grove, Illinois: InterVarsity Press, 2008.

Brownjohn, Tony, and Ian Hunter. In Trust a New Zealand Story: The History of Lichfield Lands, Longview Trust, Hillview Trust, Arohanui Trust, and Trinity Lands. Hunter Publishing, 2016.

Brunner, Daniel L., Jennifer L. Butler, and A.J. Swoboda. Introducing Evangelical Ecotheology: Foundations in Scripture, Theology, History, and Praxis. Michigan: Baker Publishing Group, 2014.

Burke, Peter. "Winter Grazing: Moving Away from Muddy Cows." https:// www.ruralnewsgroup.co.nz/dairy-news/dairy-management/winter-grazing-moving-awayfrom-muddy-cows (accessed 20 August 2019). 
Carroll, John E. Sustainability and Spirituality. Albany, New York: State University of New York Press, 2004.

Chandar, Sonita. "Faith, Family and Farming." https://farmersweekly.co.nz/section/othersectors/on-farm-story/faith-family-and-farming (accessed 3 November 2019).

Dairy Australia. "Bobby Calves.” https://www.dairyaustrailia.com.au/farm/animal-management/ animal-welfare/bobby-calves (accessed 2 February 2020).

Dairy Barn System. "Sharemilking and Dairy Farming.” https://www.dairybarnsystems.co.nz/ knowledge-centre/sharemilking-and-dairy-farming/ (accessed 2 February 2020).

DairyNZ. "Down Cows.” https://www.dairynz.co.nz/animal/cow-health/down-cows/ (accessed 20 August 2019).

—. "Grazing the Winter Crop." https://www.dairynz.co.nz/feed/crops/wintering-cows-oncrops/grazing-the-winter-crop/ (accessed 20 August 2019).

—. “Once A Day Milking.” https://www.dairynz.co.nz/milking/once-a-day-milking/ (accessed 2 July 2019).

Davidson, Allen K. Christianity in Aotearoa: A history of church and society in New Zealand. Wellington: Education for Ministry, 1991.

Davis, Ellen F. Scripture, Culture, and Agriculture: An Agrarian Reading of the Bible. New York: Cambridge University Press, 2009.

De Boo, Jasmijn. "New Zealand's Dirty Dairy.” https://www.huffpost.com/entry/new-zealandsdirty-dairy_b_14717214 (accessed 3 November 2019).

Department of Conservation. Protecting New Zealand's Rivers. PDF File. 2011. https:// www.doc.govt.nz/about-us/statutory-and-advisory-bodies/nz-conservation-authority/ publications/protecting-new-zealand-rivers/.

Dominy, Michele D. "Hearing Grass, Thinking Grass: Post-Colonialism and Ecology in Aotearoa-New Zealand.” Cultural Geographies 9 (2002): 15-34.

Environment Foundation. "Environmental Impacts of Agriculture.” http://www.environmentguide.org.nz/activities/agriculture/environmental-impacts-ofagriculture/ (accessed 23 March 2019).

Fick, Gary W. Food, Farming, and Faith. Albany, New York: SUNY Press, 2008. 
Fonterra. “About.” https://www.fonterra.com/nz/en/about.html (accessed 28 May 2019).

_. "Shareholders' Council.” https://www.fonterra.com/nz/en/about/governance/ shareholders-council.html (accessed 30 January 2020).

_. "Sustainability Report 2019." https://www.fonterra.com/nz/en/what-we-stand-for/ sustainability/Sustainability-report-2019.html (accessed 20 January 2020).

Glenna Leland L., and Curtis W. Stofferahn. "When 'Farming and Faith Collide': The Role of Agrarianism and Libertarianism in the Opposition to the ELCA's Statement on Genetics and Faith.” Journal of Lutheran Ethics 18, no. 2 (2018).

Goodchild, Philip. "Debt, Epistemology and Ecotheology." Ecotheology: Journal of Religion, Nature \& the Environment 9, no. 2 (2004): 151-77.

Gottlieb, Roger S. A Greener Faith: Religious Environmentalism and Our Planet's Future. Oxford: Oxford University Press, 2006.

Hallman, David G., ed. Ecotheology: Voices from South and North. Geneva, Switzerland: WWC Publications, 1994.

Haluza-DeLay, R. "Churches Engaging the Environment: An Autoethnography of Obstacles and Opportunities." Research in Human Ecology, 15, no. 1 (2008): 71-81.

Hassanein, Neva, and Jack R. Kloppenburg Jr. "Where the Grass Grows Again: Knowledge Exchange in the Sustainable Agriculture Movement." Rural Sociology 60, no. 4 (1995): 721-40.

Herud, Glen. "Factory Farms are Killing Off Family Farms, but All is Not Lost." https:// www.stuff.co.nz/business/112442169/family-farms-going-out-of-business-butsmallscale-dairying-could-still-be-the-future (accessed 23 May 2019).

The Holy Bible, English Standard Version. Good News Publishers, 2001.

Hughes-D’Aeth, Tony. "Friday Essay: Dark Emu and the Blindness of Australian Agriculture." https://theconversation.com/friday-essay-dark-emu-and-the-blindness-of-australianagriculture-97444 (accessed 23 May 2019).

Ikerd, John E. Crisis \& Opportunity: Sustainability in American Agriculture. University of Nebraska Press, 2008.

—. A Return to Common Sense. R.T. Edwards, Inc., 2007. 
Johnsen, Sarah. "Contingency Revealed: New Zealand Farmers' Experiences of Agricultural Restructuring." Sociologia Ruralis 43, no. 2 (2003): 128-53.

Kirschenmann, F.Cultivating an Ecological Conscience: Essays from a Farmer Philosopher. Berkeley, CA: Counterpoint, 2010.

Kramer, Kyle T. A Time to Plant. Ava Maria Press, 2001.

Lewis, Glenda. “Is the Vilification of NZ's Meat and Dairy Justified?" https://www.noted.co.nz/ health/health-nutrition/is-vilification-of-new-zealands-meat-and-dairy-justified (accessed 4 January 2020).

McPhail, Robyn. "Rural Spirituality: A Pakeha South Islander Reflects." In Land and Place: Spiritualities from Aotearoa New Zealand, ed. Helen Bergin and Susan Smith, 115-131. Auckland, NZ: Accent Publications, 2004.

_ . "Theological Reflection on Sustainable Farming and Sustainable Rural Communities." Knox Centre for Ministry and Leadership: 1-28, 2008.

Mid-Atlantic Gardening. "Polyface Farms: Pigaerators and Eggmobiles." http:// midatlanticgardening.com/polyface-farms-pigaerators-and-eggmobiles/ (accessed 2 February 2020).

Ministry for the Environment. Enterprise: Your Business and the Triple Bottom Line. PDF File. https://www.mfe.govt.nz/sites/default/files/enterprise3-triple-bottom-line-guidejun03.pdf. 2003.

Miskotte, H.H. God's Own Green Paradise: New Zealand's Churches and the Environment. Maastricht, The Netherlands: Shaker Publishing, 1997.

Northcott, Michael S. The Environment \& Christian Ethics. Cambridge, England: Cambridge University Press, 1996.

Oana. "The Importance of Ecological Farming." https://agronomag.com/importance-ecologicalfarming/ (accessed 14 May 2019).

Park, Geoff. Ngā Uruora: The Groves of Life - Ecology \& History in a New Zealand Landscape. Wellington: Victoria University Press, 1995. 
Piddock, Gerald. “Kiwis Warned Off ‘Mega-Dairy’ Farming Model.” http://www.stuff.co.nz/ business/farming/dairy/10037881/Kiwis-warned-off-mega-dairy-farming-model (accessed 4 June 2019).

Pomeroy, Ann. "Resilience of Family Farming 1984-2014: Case studies from two sheep/ beef hill country districts of New Zealand." New Zealand Geographer 71, no. 3 (2015): 146-58.

Redclift, Michael. “Sustainable Development.” In The Companion to Development Studies, ed. Vandana Desai and Robert B. Potter, 275-78. London: Arnold Publishers, 2002.

Regenerative Agriculture Initiative and The Carbon Underground. What is Regenerative Agriculture? PDF File. http://2igmzc48tf4q88z3o24qjfl8.wpengine.netdna-cdn.com/wpcontent/uploads/2017/02/Regen-Ag-Definition-2.23.17-1.pdf. 2017.

RNZ. "Water Pollution Now Public's Top Concern.” https://www.radionz.co.nz/ news/national/379343/water-pollution-now-public-s-top-concern (accessed 26 March 2019).

Santmire, H. Paul. The Travail of Nature: The Ambiguous Ecological Promise of Christian Theology. Philadelphia, Pennsylvania: Fortress Press, 1985.

Schaeffer, Francis A. Pollution and the Death of Man. Wheaton, Illinois: Tyndale House Publishers, 1970.

Scoop Politics. "Top Environmental Issues: Water, Agriculture, Climate Change.” http://www.scoop.co.nz/stories/PO1702/S00203/top-environmentalissues-water-agriculture-climate-change.htm (accessed 25 March 2019).

Sharpe, Matthew. "Name It and Claim It: Prosperity Gospel and the Global Pentecostal Reformation." In Handbook of Research on Development and Religion, ed. Matthew Clarke, 164-168. Edward Elgar Publishing Limited, 2013.

Smith, Willie, and L. Saunders. "Agricultural Policy Reforms and Sustainable Land Management: A New Zealand Case Study.” Australian Geographer 26 (1995): 112-18.

Tearfund. "Who We Are.” https:/www.tearfund.org.nz/About-Us.aspx (accessed 29 July 2019). 
Taunton, Esther. “Cows in Mud: Images Stir Up Winter Cropping Concerns Once More.” https:// www.stuff.co.nz/business/farming/114607024/cows-in-mud-new-images-stir-upcropping-concerns-once-more (accessed 20 August 2019).

Vidal, John. “A Switch to Ecological Farming.” https:/www.theguardian.com/environment/ 2016/jun/02/a-switch-to-ecological-farming-will-benefit-health-and-environment-report (accessed 31 March 2019).

Wirzba, Norman. “Agrarian Ecotheology.” Theology 116, no. 1 (2013): 36-38.

Young, Sam. "Dick Hubbard - an Authentic Leader.” http://www.samyoung.co.nz/2011/03/dickhubbard-authentic-leader.html (accessed 4 November 2019). 